\title{
Field Observations During the Fourth Microwave Water and Energy Balance Experiment (MicroWEX-4): from March 10 - June 14, $2005^{1}$
}

Joaquin Casanova, Tzu-yun Lin, Mi-young Jang, Kai-Jen Calvin Tien, Jasmeet Judge, Orlando Lanni, and Larry Miller ${ }^{2}$

1. This document is Circular 1483, one of a series of the Agricultural and Biological Engineering Department, Florida Cooperative Extension Service, Institute of Food and Agricultural Sciences, University of Florida. First published November 2005. Please visit the EDIS Web site at http://edis.ifas.ufl.edu.

2. Jasmeet Judge is an Assistant Professor and Director of Center for Remote Sensing (email: jasmeet@ufl.edu); Joaquin Casanova is an Undergraduate Research Assistant; Tzu-yun Lin, Kai-Jen Tien, and Mi-young Jang are Graduate Research Assistants; and Orlando Lanni and Larry Miller are Engineers. All authors are affiliated with the Agricultural and Biological Engineering Department, Institute of Food and Agricultural Sciences, University of Florida, Gainesville, 32611

The Institute of Food and Agricultural Sciences (IFAS) is an Equal Opportunity Institution authorized to provide research, educational information and other services only to individuals and institutions that function with non-discrimination with respect to race, creed, color, religion, age, disability, sex, sexual orientation, marital status, national origin, political opinions or affiliations. U.S. Department of Agriculture, Cooperative Extension Service, University of Florida, IFAS, Florida A. \& M. University Cooperative Extension Program, and Boards of County Commissioners Cooperating. Larry Arrington, Dean 


\section{TABLE OF CONTENTS}

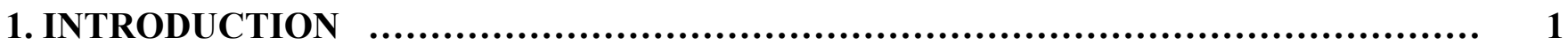

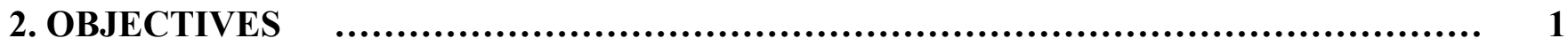

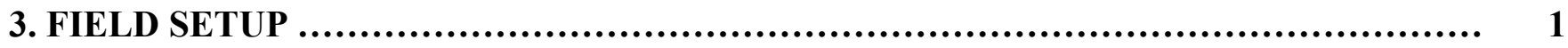

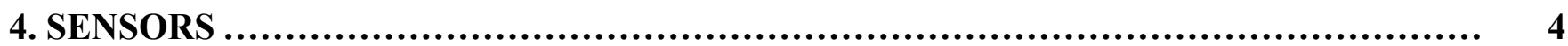

4.1 University of Florida C-band Microwave Radiometer (UFCMR) System $\quad$............ 4

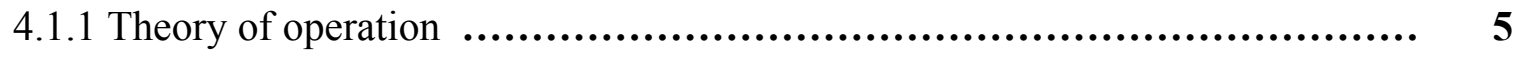

4.2 Eddy Covariance System ................................................................ 7

4.3 Net Radiometer $\quad$......................................................................... 8

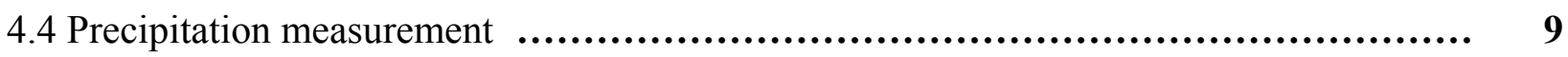

4.5 Soil Moisture and Temperature Probes................................................... 9

4.6 Thermal Infrared Sensor $\quad$.................................................. 9

4.7 Soil Heat Flux Plates.................................................................. 10

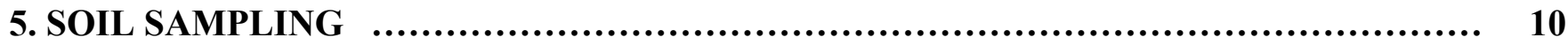

5.1 Soil Surface Roughness ............................................................... 10

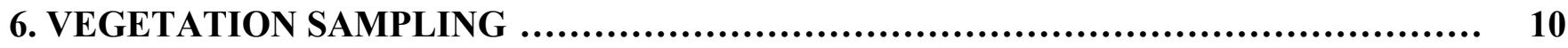

6.1 Height and Width............................................................................... 10

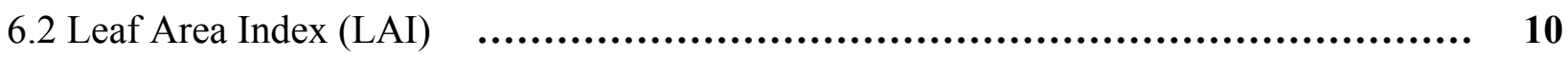

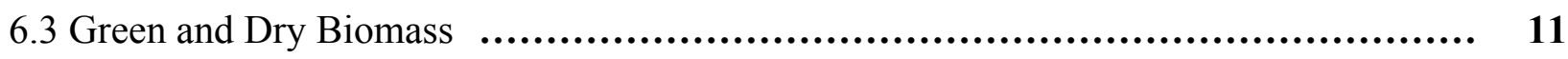

6.4 Vertical Distribution of Moisture in the Canopy ......................................... 11

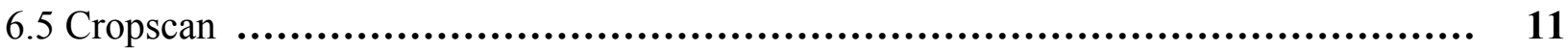

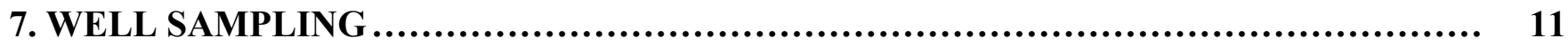

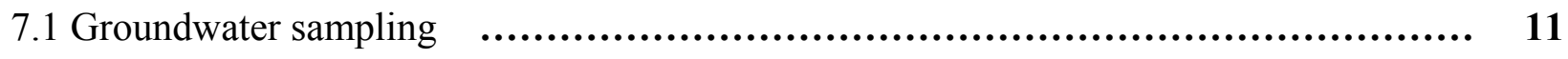

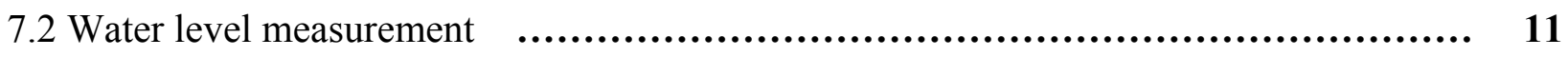

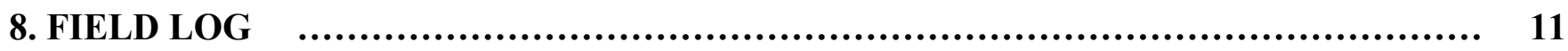

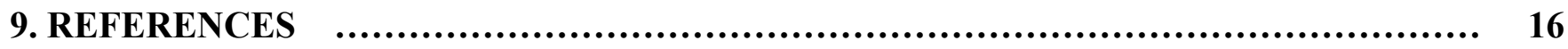

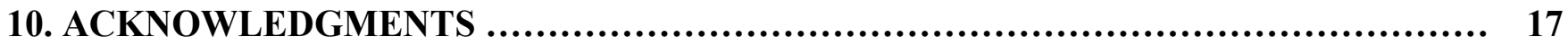

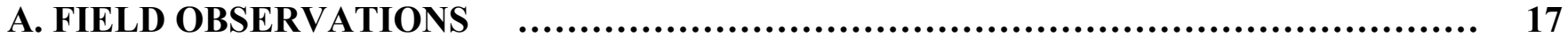




\section{INTRODUCTION}

For accurate prediction of weather and near-term climate, root-zone soil moisture is one of the most crucial components driving the surface hydrological processes. Soil moisture in the top meter is also very important because it governs moisture and energy fluxes at the land-atmosphere interface and it plays a significant role in partitioning of the precipitation into runoff and infiltration.

Energy and moisture fluxes at the land surface can be estimated by Soil-Vegetation-Atmosphere-Transfer (SVAT) models. These models are typically used in conjunction with climate prediction models and hydrological models. Even though the biophysics of moisture and energy transport is well-captured in most current SVAT models, the computational errors accumulate over time and the model estimates of soil moisture diverge from reality. One promising way to improve significantly model estimates of soil moisture is by assimilating remotely sensed data that is sensitive to soil moisture, for example microwave brightness temperatures, and updating the model state variables.

The microwave brightness at low frequencies $(<10 \mathrm{GHz})$ is very sensitive to soil moisture in the top few centimeters in most vegetated surfaces. Many studies have been conducted in agricultural areas such as bare soil, grass, soybean, wheat, pasture, and corn to understand the relationship between soil moisture and microwave remote sensing. Most of these experiments conducted in agricultural regions have been shortterm experiments that captured only a part of growing seasons. It is important to know how microwave brightness signature varies with soil moisture, evapotranspiration (ET), and biomass in a dynamic agricultural canopy with a significant biomass $\left(4-6 \mathrm{~kg} / \mathrm{m}^{2}\right)$ throughout the growing season.

\section{OBJECTIVES}

The goal of MicroWEX-4 was to understand the land-atmosphere interactions during the growing season of corn, and their effect on observed microwave brightness signatures at $6.7 \mathrm{GHz}$, matching that of the satellite based microwave radiometer, AMSR. Specific objectives of MicroWEX-4 are:

1. To collect passive microwave and other ancillary data to develop and calibrate a dynamic microwave brightness model for corn.

2. To collect energy and moisture flux data at land surface and in soil to develop and calibrate a dynamic SVAT model for corn.

3. To evaluate feasibility of soil moisture retrievals using passive microwave data at $6.7 \mathrm{GHz}$ for the growing corn canopy.

4. To evaluate feasibility of using Mid Infrared Reflectance for estimating vegetation water content and biomass during the corn growing season

\section{FIELD SETUP}

MicroWEX-4 was conducted by the Center for Remote Sensing, Agricultural and Biological Engineering Department, at the Plant Science Research and Education Unit (PSREU), IFAS, Citra, FL. Figures 1 and 2 show the location of the PSREU and the study site for the MicroWEX-4, respectively. The study site was located at the west side of the PSERU. The dimensions of the study site were $183 \mathrm{~m} \mathrm{X} 183 \mathrm{~m}$. A linear move system was used for irrigation. The corn planting began on March 10 (Day of Year (DoY) 69) in 2005, at an orientation $60^{\circ}$ from East as shown in Figure 3. On March 10, only 2-3 rows were planted; on March 11, all but the southwest corner was planted; and on the March 12, planting was completed. The crop spacing was about $8 \mathrm{~cm}$ and the row spacing was $76.2 \mathrm{~cm}$ (30 inches). Instrument installation began on March 14 (DoY 73). The instruments consisted of a ground-based microwave radiometer system and micrometeorological stations. The ground-based microwave radiometer system was installed at the location shown in Figure 3, facing south to avoid the radiometer shadow interfering with the field of view as seen in Figure 3. 


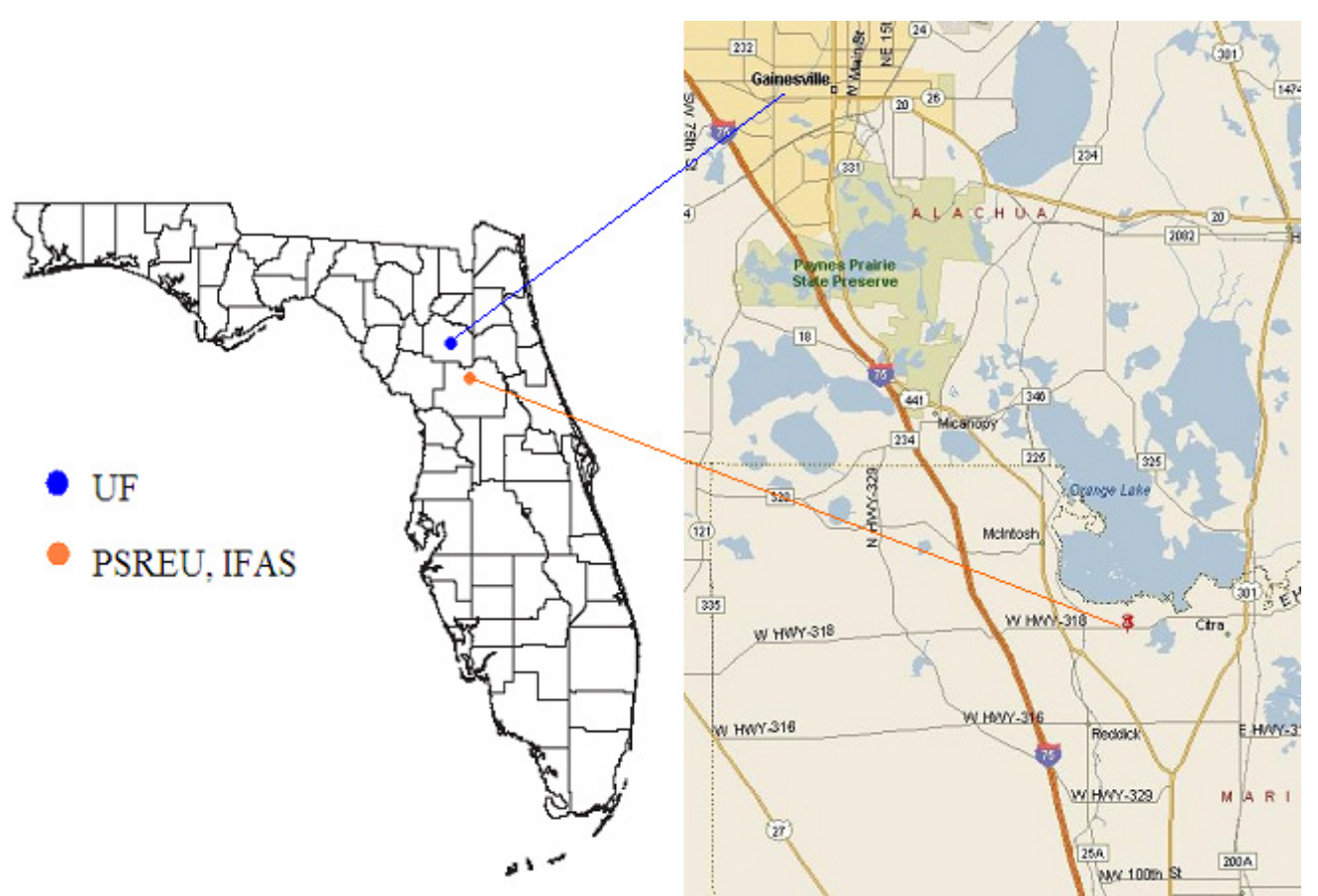

Figure 1. Location of PSREU/IFAS (from http://plantscienceunit.ifas.ufl.edu/directions.htm)

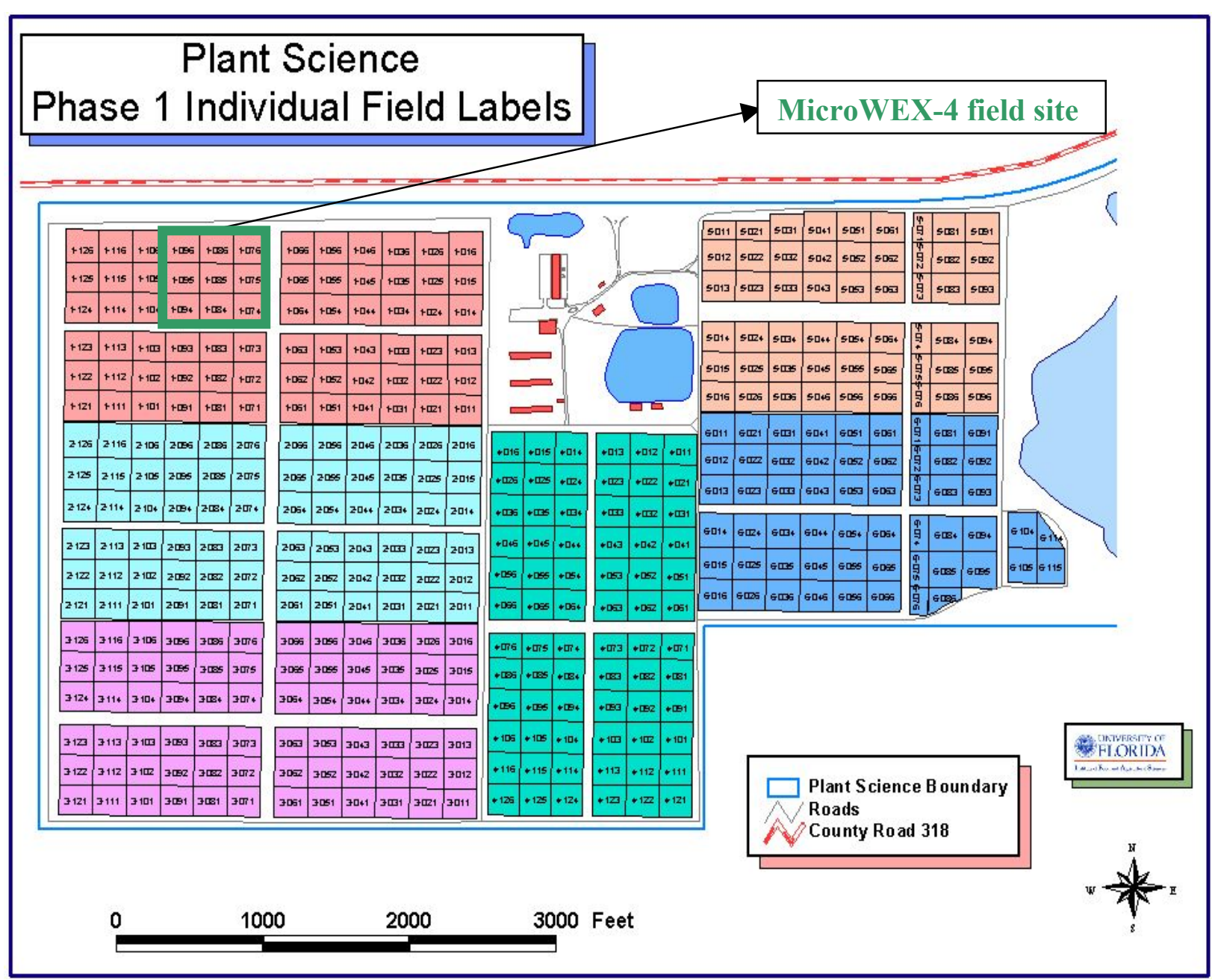

Figure 2. Location of the field site for MicroWEX-4 at the UF/IFAS PSREU (from http://plantscienceunit.ifas.ufl.edu/images/location/p1.jpg) 
The micrometeorological station was installed at the center of the field and included soil heat flux plates and the eddy covariance system. Two raingauges were installed at the east and west edge of the radiometer footprint. Two additional raingauges also were installed at the east and west edge of the field to capture the irrigation. Three stations with soil moisture, soil heat flux, and soil temperature sensors installed were set up at the location shown in Figure 3. A Thermal infrared camera and a net radiometer were installed at the Northwest station. This report provides detailed information regarding sensors deployed and data collected during the MicroWEX-4.

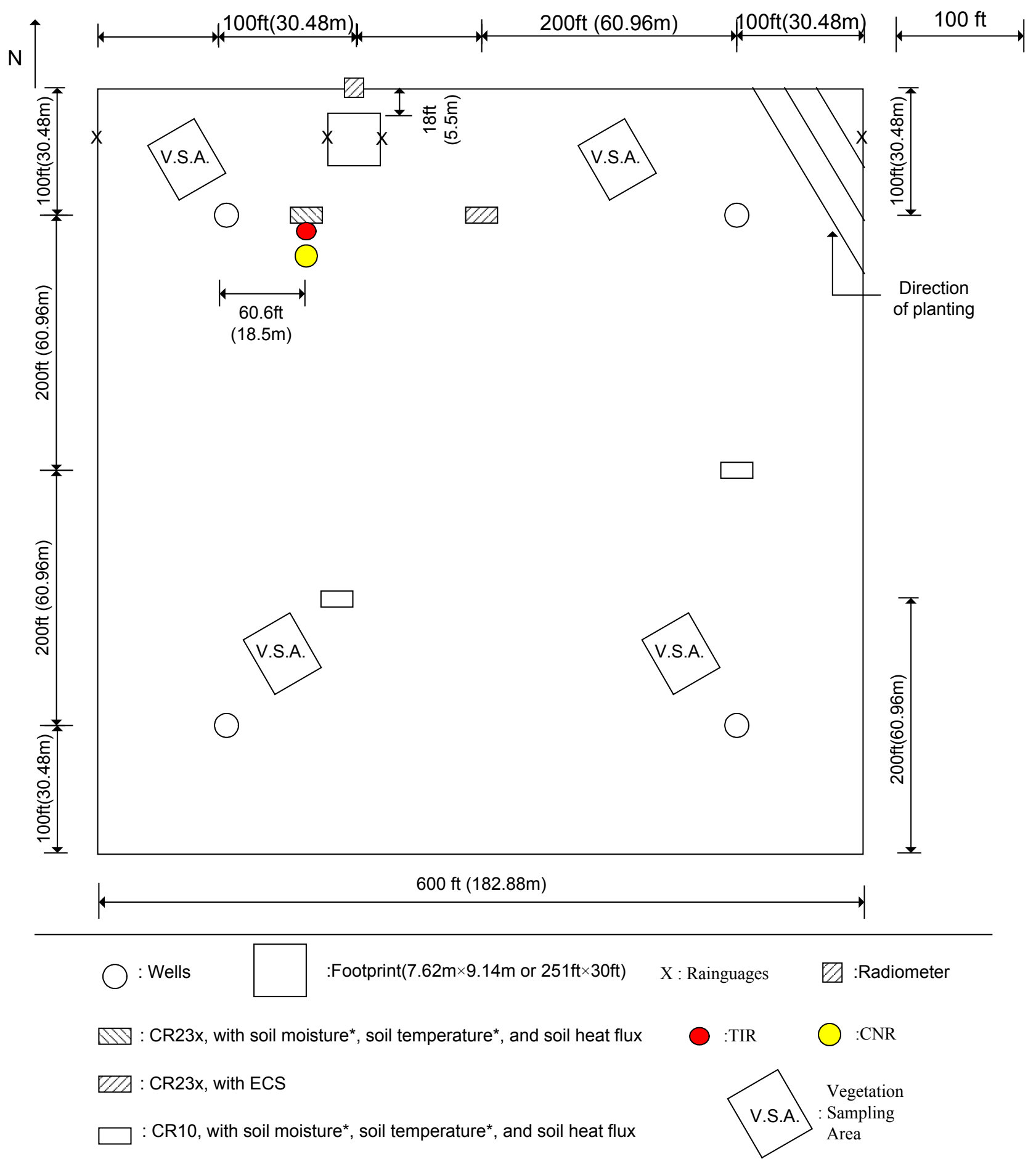

*: The sensors are installed at depth: 2, 4, 8, 16, 32, 64, and $120 \mathrm{~cm}$

Figure 3. Layout of the sensors during MicroWEX-4. 


\section{SENSORS}

MicroWEX-4 had three major types of instrument subsystems: the ground-based University of Florida Cband Radiometer (UFCMR), the micrometeorological subsystem, and the soil subsystem.

\subsection{University of Florida C-band Microwave Radiometer (UFCMR) System}

Microwave brightness temperatures at $6.7 \mathrm{GHz}(\lambda=4.48 \mathrm{~cm})$ were measured every 30 minutes using the University of Florida's C-band Microwave Radiometer system (UFCMR) (Figure 4 (a)). The radiometer system consisted of a dual polarization total power radiometer operating at the center frequency of $6.7 \mathrm{GHz}$ housed atop a $10 \mathrm{~m}$ tower installed on a 16' trailer bed. UFCMR was designed and built by the Microwave Geophysics Group at the University of Michigan. It operates at the center frequency at $6.7 \mathrm{GHz}$ which is identical to one of the center frequencies on the space borne Advanced Microwave Scanning Radiometer (AMSR) aboard the NASA Aqua Satellite Program. The UFCMR observed a footprint of size $7.62 \mathrm{~m} \times 9.14$ $\mathrm{m}$ from a height of $6.17 \mathrm{~m}$. A rotary system was used to rotate the look angle of the UFCMR both for field observations and sky measurements. The brightness temperatures were observed at an incidence angle of $55^{\circ}$ matching that of the space borne AMSR-E sensor. The radiometer was calibrated every two weeks with a microwave absorber as warm load and measurements of sky at several angles as cold load. Figures 4 (b) and 4 (c) show the close-up of the rotary system and the antenna of the UFCMR, respectively. Table 1 lists the specifications of UFCMR. Figure A-1 shows the V- \& H-pol brightness temperatures observed during MicroWEX-4.

Table 1. UFCMR specifications

\begin{tabular}{|l|l|l|}
\hline Parameter & Qualifier & Value \\
\hline Frequency & Center & $6.7 \mathrm{GHz}$ \\
\hline Bandwidth & $3 \mathrm{~dB}$ & $20 \mathrm{MHz}$ \\
\hline \multirow{5}{*}{ Beamwidth } & $3 \mathrm{~dB}$ V-pol elevation & $23^{\text {oa }}$ \\
\cline { 2 - 3 } & $3 \mathrm{~dB}$ V-pol azimuth & $21^{\text {ob }}$ \\
\cline { 2 - 3 } & $3 \mathrm{~dB}$ H-pol elevation & $21^{\circ \mathrm{c}}$ \\
\cline { 2 - 3 } & $3 \mathrm{~dB}$ H-pol azimuth & $23^{\text {od }}$ \\
\hline Isolation & & $>27 \mathrm{~dB}$ \\
\hline Polarizations & Sequential & $\mathrm{V} / \mathrm{H}$ \\
\hline Receiver temp & & $437 \mathrm{~K}^{\mathrm{e}}$ \\
\hline Noise Figure & From Trec & $3.99 \mathrm{~dB}$ \\
\hline RF gain & & $85 \mathrm{~dB}$ \\
\hline Gain tempco & dTsys/dTset & $-2 \mathrm{~K}^{\mathrm{f}}$ \\
\hline \multirow{3}{*}{ NEDT } & $1 \mathrm{sec}$ & $0.71 \mathrm{~K}^{\mathrm{g}}$ \\
\cline { 2 - 3 } & $8 \mathrm{sec}$ & $0.25 \mathrm{~K}$ \\
\hline Tempature & Control - rms & $5 \mathrm{mK}^{\mathrm{i}}$ \\
\hline SetPoint & Max & $40^{\circ} \mathrm{C}^{\mathrm{j}}$ \\
\cline { 2 - 3 } & Min & $0^{\circ} \mathrm{C}$ \\
\hline Ambient & Max & $48^{\circ} \mathrm{C}^{\mathrm{k}}$ \\
\cline { 2 - 3 } & Min & $<0^{\circ} \mathrm{C}^{\mathrm{l}}$ \\
\hline RF cutout & McShane or RF1 thermistor & $42^{\circ} \mathrm{C}^{\mathrm{m}}$ \\
\hline Thermal shutdown & Case thermistor & $62^{\circ} \mathrm{C}^{\mathrm{n}}$ \\
\hline
\end{tabular}

(a). sidelobes $<-33 \mathrm{~dB}$, (b). sidelobes $<-28 \mathrm{~dB}$, (c). sidelobes $<-27 \mathrm{~dB}$, (d). sidelobes $<-35 \mathrm{~dB}$, (e). +/- $20 \mathrm{~K}$ uncertainty, (f). looking at reference load, $(\mathrm{g})$. tracking of absorber to reference load in lab, Tset $=305 \mathrm{~K}$ with PID $=0.75,0.94,0$, (h). tracking of absorber to reference load in lab, Tset $=305 \mathrm{~K}$ with PID $=0.75,0.94,0$, (i). Tset $=305 \mathrm{~K}$ in lab environment, on RF2, over 0.5 hour, after a day running, (j). active components rated to $65 \mathrm{C}$, filters to $40 \mathrm{C}$, (k). estimated absolute max Tamb-Tset $=15 \mathrm{C}$ at TEC 100\% cooling, (1). estimated, (m). RF power cut only, user recovery only, (n). RF and TEC power, user recovery only. 


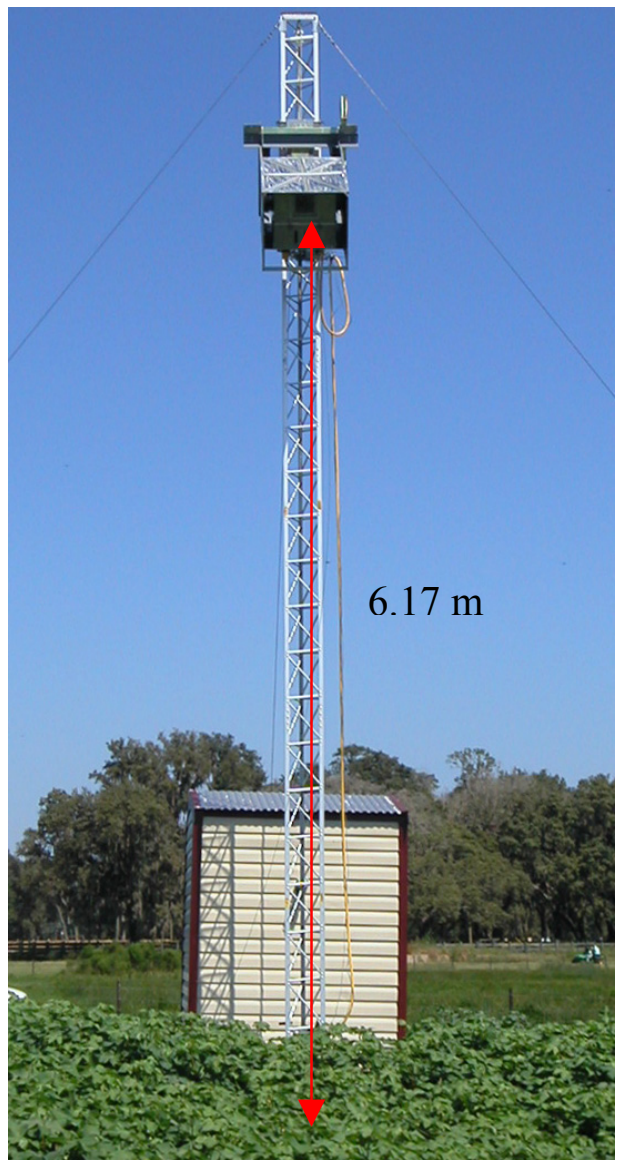

Figure 4 (a).The UFCMR system
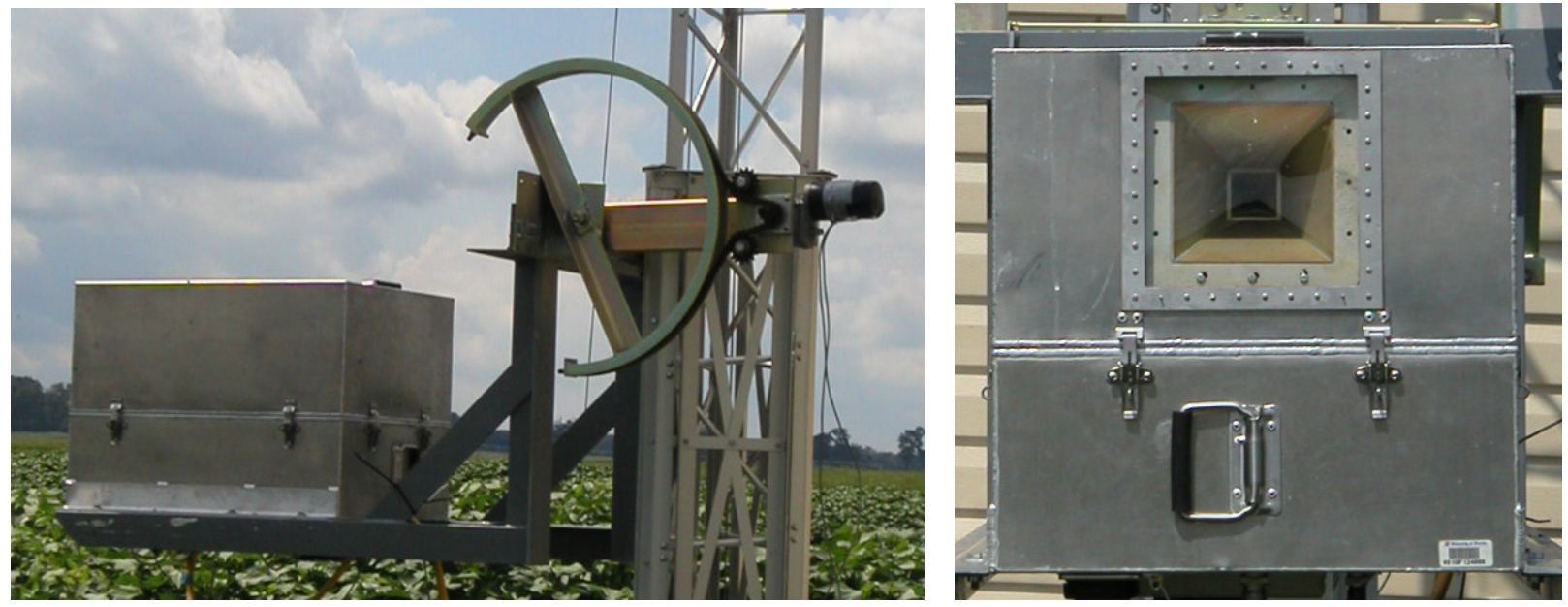

Figure 4 (b) and (c). The side view of the UFCMR showing the rotary system and the front view of the UFCMR showing the receiver antenna.

\subsubsection{Theory of operation}

UFCMR uses a thermoelectric cooler (TEC) for thermal control of the Radio Frequency (RF) stages for the UFCMR. This is accomplished by the Oven Industries "McShane" thermal controller. McShane is used to cool or heat by Proportional-Integral-Derivative (PID) algorithm with a high degree of precision at $0.01{ }^{\circ} \mathrm{C}$. The aluminum plate to which all the RF components are attached is chosen to have sufficient thermal mass to eliminate short-term thermal drifts. All components attached to this thermal plate, including the TEC, use thermal paste to minimize thermal gradients across junctions. 
The majority of the gain in the system is provided by a gain and filtering block designed by the University of Michigan for the STAR-Light instrument (De Roo, 2003). The main advantage of this gain block is the close proximity of all the amplifiers, simplifying the task of thermal control. This gain block was designed for a radiometer working at the radio astronomy window of 1400 to $1427 \mathrm{MHz}$, and so the receiver is a heterodyne type with downconversion from the $\mathrm{C}$-band $\mathrm{RF}$ to $\mathrm{L}$-band. To minimize the receiver noise figure, a C-band low-noise amplifier (LNA) is used just prior to downconversion. To protect the amplifier from saturation due to out of band interference, a relatively wide bandwidth, but low insertion loss, bandpass filter is used just prior to the amplifier. Between the filter and the antenna are three components: a switch for choosing polarization, a switch for monitoring a reference load, and an isolator to minimize changes in the apparent system gain due to differences in the reflections looking upstream from the LNA.

The electrical penetrations use commercially available weatherproof bulkhead connections (Deutsch connectors or equivalent). The heat sinks have been carefully located employing RTV (silicone sealant) to seal the bolt holes. The radome uses $15 \mathrm{mil}$ polycarbonate for radiometric signal penetration. It is sealed to the case using a rubber gasket held down to the case by a square retainer.

The first SMA connection electomechanical latching, which is driven by the Z-World control board switches between V-and H-polarization sequentially. The SMA second latching which switches between the analog signal from the first switch and the reference load signal from a reference load resistor sends the analog signal to a isolator, where the signals within 6.4 to $7.2 \mathrm{GHz}$ in radiofrequency are isolated. Then the central frequency is picked up by a $6.7 \mathrm{GHz}$ bandpass filter, which also protects the amplifier to saturation. A Low Noise Amplifier (LNA) is used to eliminate the noise figure and adjust gain. A mixer takes the input from the LNA and a local oscillator to output a $1.4 \mathrm{GHz}$ signal to STAR-Lite. After the Power Amplifier and Filtering Block (Star-Lite back-end), the signal is passed through a Square Law Detector and a PostDetection Amplifier. UFCMR is equipped with a microcontroller that has responsibility for taking measurements, monitoring the thermal environment, and storing data until a download is requested. A laptop computer is used for running the user interface named FluxMon to communicate with the radiometer through Radiometer Control Language (RadiCL). The radiometer is configured to maintain a particular thermal set point, and make periodic measurements of the brightness at both polarizations sequentially and the reference load. The data collected by the radiometer is not calibrated within the instrument, since calibration errors could corrupt an otherwise useful dataset. Figure 5 shows the block diagram of UFCMR. 


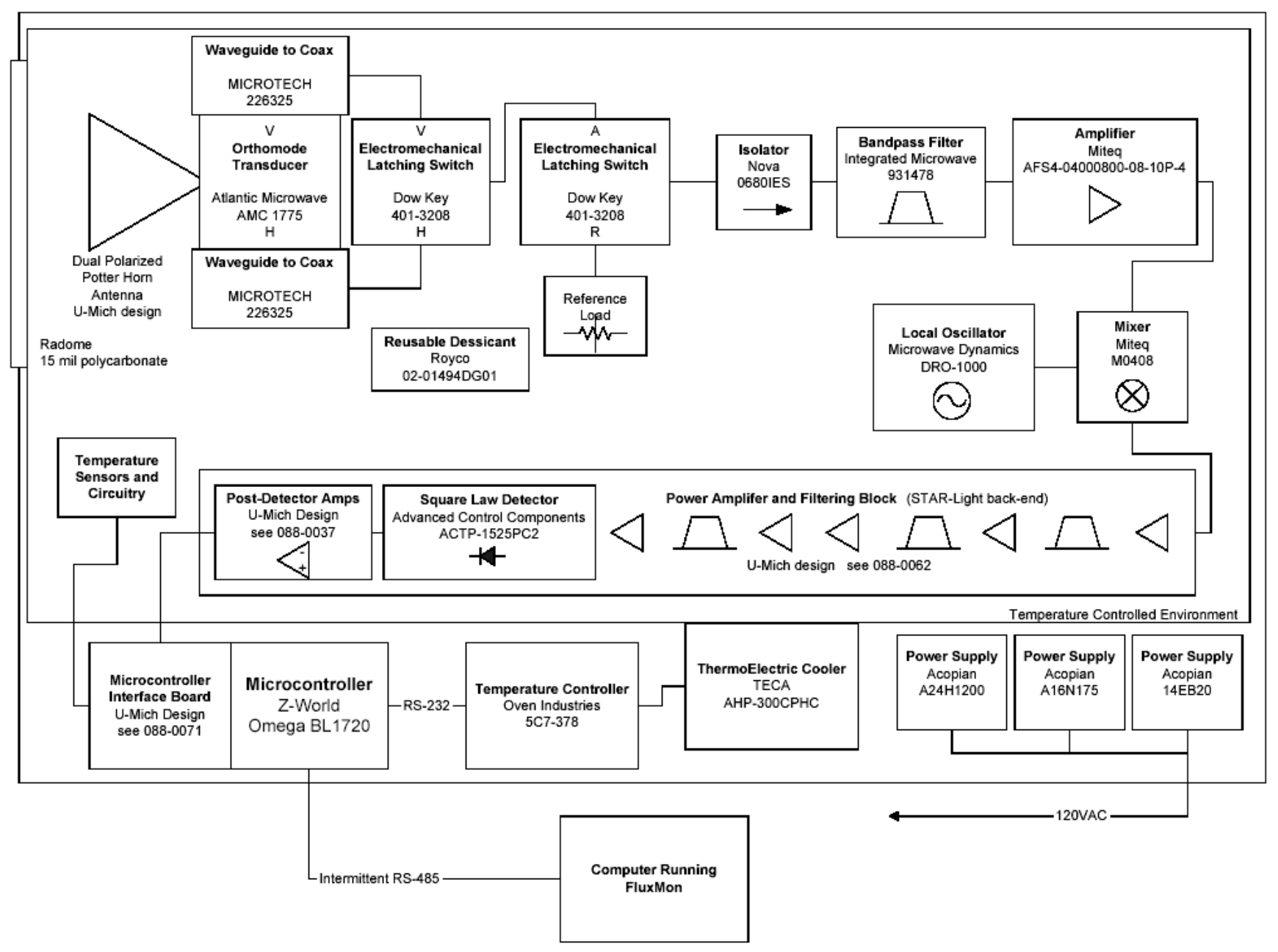

Figure 5. Block diagram of the University of Florida C-band Radiometer (De Roo, 2002).

\subsection{Eddy Covariance System}

A Campbell Scientific eddy covariance system was located at the center of the field also shown in Figure 3. Figure 6 shows the close-up of the sensor. The system included a CSAT3 anemometer and KH20 hygrometer. CSAT3 is a three dimensional sonic anemometer, which measures wind speed and the speed of sound on three non-orthogonal axes. Orthogonal wind speed and sonic temperature are computed from these measurements. KH20 measures the water vapor in the atmosphere. Its output voltage is proportional to the water vapor density flux. Latent and sensible heat fluxes were measured every 30 minutes. The height of the eddy covariance system was about $1 \mathrm{~m}$ from the ground and the orientation of the system was $232^{\circ}$ toward southwest. On DoY 143 the sensor was moved to $2.1 \mathrm{~m}$. Table 2 shows the list of specifications of the CSAT3. Data collected by the eddy covariance system have been processed for coordinate rotation (Kaimal and Finnigan, 1994; Wilczak et al., 2001), WPL (Web et al., 1980), oxygen (van Dijk et al., 2003, 2004), and sonic temperature corrections (Schotanus et al., 1983). Figure A-2 shows the processed latent and sensible heat fluxes observed during MicroWEX-4. 


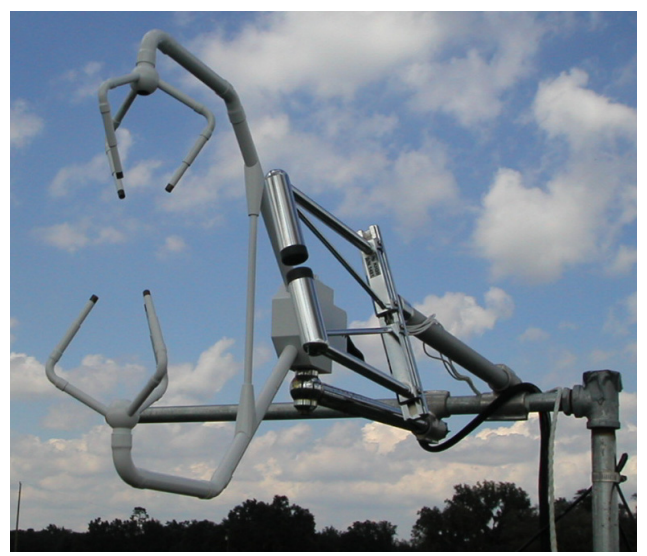

Figure 6. Eddy covariance system

Table 2. Specifications of the CSAT3 (Campbell Scientific, 1998)

\begin{tabular}{|l|l|}
\hline \multicolumn{1}{|c|}{ Description } & \multicolumn{1}{c|}{ Value } \\
\hline Measurement rate & 1 to $60 \mathrm{~Hz}$ \\
\hline Noise equivalent wind & $1 \mathrm{~mm} / \mathrm{sec}$ in horizontal wind speed and \\
& $0.5 \mathrm{~mm} / \mathrm{sec}$ in vertical wind speed \\
\hline Wind measurement offset & $< \pm 4 \mathrm{~cm} / \mathrm{sec}$ over -30 to $50^{\circ} \mathrm{C}$ \\
\hline Output signals & Digital SDM or RS-232 and Analog \\
\hline Digital output signal range & $\pm 65.535 \mathrm{~m} / \mathrm{sec}$ in wind speed and 300 to $366 \mathrm{~m} / \mathrm{sec}$ in speed of sound \\
\hline Digital output signal resolution & 0.25 to $2 \mathrm{~mm} / \mathrm{sec}$ in vertical wind speed and $1 \mathrm{~mm} / \mathrm{s}$ in speed of sound \\
\hline Analog output signal range & \pm 32.768 to $\pm 65.536 \mathrm{~m} / \mathrm{sec}$ in wind speed and 300 to $366 \mathrm{~m} / \mathrm{sec}$ in speed of sound \\
\hline Analog output signal resolution & $\pm 8.192 \mathrm{~mm} / \mathrm{sec}$ in vertical wind speed and $16 \mathrm{~mm} / \mathrm{sec}$ in speed of sound \\
\hline Measurement path length & $10.0 \mathrm{~cm}$ vertical and $5.8 \mathrm{~cm}$ horizontal \\
\hline Transducer path angle from horizontal & 60 degrees \\
\hline Transducer & $0.64 \mathrm{~cm}$ in diameter \\
\hline Transducer mounting arms & $0.84 \mathrm{~cm}$ in diameter \\
\hline Support arms & $1.59 \mathrm{~cm}$ in diameter \\
\hline Dimensions: anemometer head & $47.3 \mathrm{~cm} \times 42.4 \mathrm{~cm}$ \\
\hline Dimensions: electronics box & $26 \mathrm{~cm} \mathrm{x} 16 \mathrm{~cm} \times 9 \mathrm{~cm}$ \\
\hline Dimensions: carry case & $71.1 \mathrm{~cm} \mathrm{x} 58.4 \mathrm{~cm} \mathrm{x} 33 \mathrm{~cm}$ \\
\hline Weight: anemometer head & $1.7 \mathrm{~kg}$ \\
\hline Weight: electronics box & $2.8 \mathrm{~kg}$ \\
\hline Weight: shipping & $16.8 \mathrm{~kg}$ \\
\hline Operating temperature range & $-30^{\circ} \mathrm{C}$ to $50^{\circ} \mathrm{C}$ \\
\hline Power requirement: voltage supply & 10 to 16 VDC \\
\hline Power requirement: current & $200 \mathrm{~mA}$ at $60 \mathrm{~Hz}$ measurement rate and $100 \mathrm{~mA}$ at $20 \mathrm{~Hz}$ measurement rate \\
\hline
\end{tabular}

\subsection{Net Radiometer}

A Kipp and Zonen CNR-1 four-component net radiometer (Figure 7) was located at the center of the field to measure up- and down-welling short- and long-wave infrared radiation. The sensor consists of two pyranometers (CM-3) and two pyrgeometers (CG-3). The sensor was installed at the height of $2.66 \mathrm{~m}$ above ground and facing south. Table 3 shows s the list of specifications of the CNR-1 net radiometer. Figure A-3 shows the up- and down-welling solar (shortwave) wave radiation observed during MicroWEX-4 and the up- and down-welling far infrared (longwave) radiation observed during MicroWEX-4. 


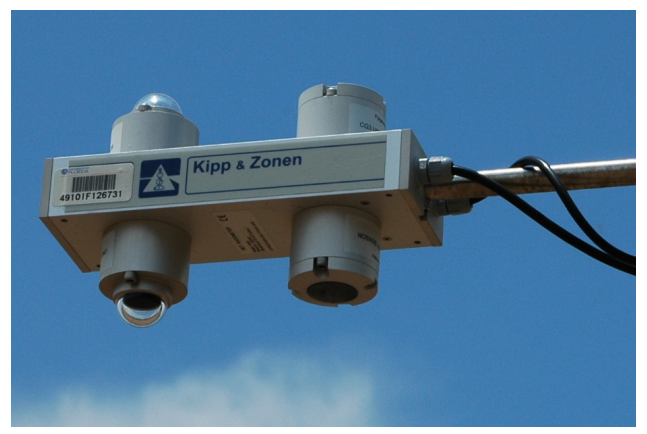

Figure 7. CNR-1 net radiometer

Table 3. Specifications of the CNR-1 net radiometer (Campbell Scientific, 2005a)

\begin{tabular}{|l|l|}
\hline \multicolumn{1}{|c|}{ Description } & \multicolumn{1}{c|}{ Value } \\
\hline Measurement spectrum: CM-3 & 305 to $2800 \mathrm{~nm}$ \\
\hline Measurement spectrum: CG-3 & 5000 t o50000 nm \\
\hline Response time & $18 \mathrm{sec}$ \\
\hline Sensitivity & 10 to $35 \mu \mathrm{V} /\left(\mathrm{W} / \mathrm{m}^{2}\right)$ \\
\hline Pt-100 sensor temperature measurement & DIN class A \\
\hline Accuracy of the Pt-100 measurement & $\pm 2 \mathrm{~K}$ \\
\hline Heating & Resistor $24 \mathrm{ohms}, 6 \mathrm{VA}$ at 12 volt \\
\hline Maximum error due to heating: CM-3 & $10 \mathrm{~W} / \mathrm{m}^{2}$ \\
\hline Operating temperature & $-40^{\circ}$ to $70^{\circ} \mathrm{C}$ \\
\hline Daily total radiation accuracy & $\pm 10^{2}$ \\
\hline Cable length & $10 \mathrm{~m}$ \\
\hline Weight & $4 \mathrm{~kg}$ \\
\hline
\end{tabular}

\subsection{Precipitation}

Precipitation was determined using four tipping-bucket raingages, two on either side of the footprint and two on either side of the field. Figure A-4 shows the observed precipitation.

\subsection{Soil Moisture and Temperature Probes}

Three standard Vitel Hydra soil moisture and temperature probes and 28 Campbell Scientific time-domain water content reflectometers (CS616 - see sensor calibration coefficients in Table 4) were used to measure soil volumetric water contents and temperatures at the depths of 2, 4, 8, 16, 32, 64, and $120 \mathrm{~cm}$ every 15 minutes. At the East station, there were also two deep TDRs, one each by the Northeast and Southeast wells at approximately $1.6 \mathrm{~m}$. At the Northwest station, the deep sensor was by the Northwest well at $1.45 \mathrm{~m}$, the Southwest deep TDR was at $1.8 \mathrm{~m}$. The observations of soil moisture were duplicated at the depth of $2 \mathrm{~cm}$ and $4 \mathrm{~cm}$. The calibration coefficients for the CS616 probes are listed in Table 2. Figure A-5 shows the soil temperatures observed at the depths of $2 \mathrm{~cm}, 4 \mathrm{~cm}, 8 \mathrm{~cm}, 16 \mathrm{~cm}, 32 \mathrm{~cm}, 64 \mathrm{~cm}$, and $120 \mathrm{~cm}$, at northwest station during MicroWEX-4. Figures A-6 and A-7 show the soil temperatures observed at the same depths at the Southwest station and East station. Figures A-8, A-9, and A-10 show the volumetric soil moisture content observed at the same depths plus the deep TDRs for the Northwest, Southwest, and East stations respectively.

Table 4. The calibration coefficients for the CS616 probes (Campbell Scientific, 2004b)

\begin{tabular}{|c|c|}
\hline Coefficient & Value \\
\hline $\mathrm{C}_{0}$ & -0.187 \\
\hline $\mathrm{C}_{1}$ & 0.037 \\
\hline $\mathrm{C}_{2}$ & 0.335 \\
\hline
\end{tabular}




\subsection{Thermal Infrared (TIR) Sensor}

An Everest Interscience thermal infrared sensor (4000.3ZL - see sensor specifications in Table 5) was collocated with the net radiometer to observe skin temperature at nadir. The sensor was installed at the height of $2.5 \mathrm{~m}$. With the sensor field of view of $15^{\circ}$, the size of the footprint for the thermal infrared sensor was $66 \mathrm{~cm} \mathrm{X} 66 \mathrm{~cm}$. There is a data gap from DoY 98 to DoY 113, and from DoY 118 to the end of the experiment due to damaged sensor. Figure A-1 shows the surface thermal infrared temperature observed during MicroWEX-4.

Table 5. Specifications of the thermal infrared sensor (Everest Interscience, 2005)

\begin{tabular}{|l|l|}
\hline \multicolumn{1}{|c|}{ Description } & \multicolumn{1}{c|}{ Value } \\
\hline Accuracy & $\pm 0.5^{\circ} \mathrm{C}$ \\
\hline Resolution & $0.1^{\circ} \mathrm{C}$ \\
\hline Measurement range & $-40^{\circ}$ to $100^{\circ} \mathrm{C}$ \\
\hline Measurement spectrum & 8 to $14 \mu \mathrm{m}$ \\
\hline Field of view & $15^{\circ}$ \\
\hline Response time & $0.1 \mathrm{sec}$ \\
\hline Operating distance & $2 \mathrm{~cm}$ to $300 \mathrm{~m}$ \\
\hline Power requirement: voltage supply & 5 to $26 \mathrm{VDC}$ \\
\hline Power requirement: current & $10 \mathrm{~mA}$ \\
\hline Output signal & $\mathrm{RS}-232 \mathrm{C}$ and analog $\mathrm{mV}\left(10.0 \mathrm{mV} /{ }^{\circ} \mathrm{C}\right)$ \\
\hline
\end{tabular}

\subsection{Soil Heat Flux Plates}

Two Campbell Scientific (2003) soil heat flux plates (HFT-3) were used to measure soil heat flux at the depths of 2 and $4 \mathrm{~cm}$, in row and near the root area, respectively in the Northwest station. The CSAT, East, and Southwest stations each had one SHF plate at $2 \mathrm{~cm}$. Figure A-11 shows the soil heat fluxes observed at all locations.

\subsection{Soil Surface Roughness}

\section{SOIL SAMPLING}

Soil roughness was measured throughout the growing season. See [Jang et al. 2005] for more detail on the roughness experiment and dataset collected.

\section{VEGETATION SAMPLING}

Vegetation properties such as stand density, row spacing, height, biomass, and LAI were measured weekly during the field experiment. The crop density derived from the stand density and row spacing was measured at the first two samplings since the corn seeds were planted in the fixed spacing and the germination rate is over $70 \%$ throughout the field. The specific weekly measurements include height, biomass, and LAI. In the whole season, the vegetation samplings were conducted on four spatially distributed sampling locations (Figure 3). It was designed to characterize the spatial variability of the vegetation properties in the study site.

\subsection{Height and Width}

Crop height and width were measured by placing a measuring stick at the soil surface to average height of the crop. Four representative plants were selected to obtain heights inside each vegetation sampling area. Crop height and width for each of the sampling areas is shown in Figure A-12.

\subsection{LAI}

LAI was measured with a Li-Cor LAI-2000 in the inter-row region with 4 cross-row measurements. The LAI-2000 was set to average 2 locations into a single value for each vegetation sampling area so one observation was taken above the canopy and 4 beneath the canopy; in the row, $1 / 4$ of the way across the row, 
$1 / 2$ of the way across the row, and $3 / 4$ of the way across the row. This gave a spatial average for row crops of partial cover. LAI for each of the sampling areas is shown in Figure A-12.

\subsection{Green and Dry Biomass}

Each biomass sampling included one row. The sampling length was measured the same as length during stand density measurement. The sample started in-between two plants and ended at the next midpoint that is also greater than or equal to one meter away from the starting point. The plants within this length were cut at the base, separated into leaves, stems, and ears, and weighed immediately. The samples were dried in the oven at $70^{\circ} \mathrm{C}$ for 48 hours and their dry weights were measured, separating the ears into husks, shucks, and kernel/cobs. Figure A-13 shows the Green and Dry biomass observed during MicroWEX-4. Dry biomass at harvest is used as yield.

\subsection{Vertical Distribution of Moisture in the Canopy}

Details of these measurements can be found in [Casanova et al. 2006].

\subsection{Cropscan}

A Cropscan MSR16R 16-band multispectral radiometer was used to measure canopy reflectance as the crop developed. For each sample, 8 readings were taken, 4 centered in-row and 4 centered between-row. The aerage reflectance for each sample at each band is shown in Figure A-14.

\section{WELL SAMPLING}

\subsection{Groundwater sampling}

The groundwater sampling was conducted by Dr. Michael Dukes and his research team. The sampling was conducted at all four wells in the field at the end of each month from March to June in 2005. The groundwater sampling included groundwater level measurement by water level sounder, and collecting groundwater samples for the analysis of $\mathrm{N}_{2}$ (Figure A-15).

\subsection{Water level measurement}

The water level measurement was processed by the Levelogger from Solinst Canada Ltd.. The Leveloggers were installed at each well and set to record automatically the water level every 15 minutes. Personnel from The data were downloaded onto a laptop during the well sampling at the end of each month. Figure A-16 shows the water table elevation and depth during MicroWEX-4.

\section{FIELD LOG}

Note: Time is in Eastern Standard Time.

March 4 (DoY 63)

\begin{tabular}{|l|l|}
\hline & Trailer set up \\
\hline & Deep TDRs at SW and NW installed \\
\hline & Field disced and prepared \\
\hline
\end{tabular}

March 10 (DoY 69)

\begin{tabular}{|l|l|}
\hline $09: 00$ & North guy wire setup \\
\hline $12: 15$ & Radiometer run over night to test \\
\hline & Planting started; only 2-3 rows completed near footprint \\
\hline
\end{tabular}


March 11 (DoY 70)

\begin{tabular}{|l|l|}
\hline $10: 00$ & Radiometer not working; problem: open circuit for thermistor \\
\hline & Radiometer brought back to lab \\
\hline & Continued planting; ran out of seed; SW corner incomplete \\
\hline
\end{tabular}

March $12($ DoY 71)

\begin{tabular}{|l|l}
\hline 10:00 & Continued planting; finished SW corner
\end{tabular}

March 13 (DoY 72)

10:00 $\quad$ Removed angle-iron from tower and brought it back to shop

Marked ET station location, row numbers, and footprint

March 14 (DoY 73)

\begin{tabular}{|l|l}
\hline 10:00 & Buried NW thermistors and TDRs \\
\hline & Radiometer brought back to field
\end{tabular}

March 15 (DoY 74)

\begin{tabular}{|l|l|}
\hline $10: 00$ & Radiometer test data downloaded \\
\hline & Temperature control tested, sky measurements \\
\hline & Set at $7.6 \mathrm{~m}$, to get terrain brightness, lowered to $\sim 6.17 \mathrm{~m}$ \\
\hline & ET sensors, raingages installed \\
\hline
\end{tabular}

$\underline{\text { March } 16(\text { DoY 75) }}$

\begin{tabular}{|l|l|}
\hline $10: 00$ & NW sensors hooked up (CNR not back, TIR not working) \\
\hline & $2 \mathrm{~cm}$ soil thermistor not working; replaced \\
\hline & Radiometer lowered to $6.17 \mathrm{~m}$ \\
\hline & ET set to work \\
\hline
\end{tabular}

March 17 (DoY 76)

10:00 Hobo raingages set up at edges of field

March 18 (DoY 77)

\begin{tabular}{|l|l|}
\hline $08: 00$ & East sensors buried and hooked up \\
\hline $11: 30$ & Southwest sensors buried \\
\hline $13: 30$ & Pesticide application \\
\hline & Some germination \\
\hline
\end{tabular}

March 21 (DoY 80)

\begin{tabular}{|l|l|}
\hline $08: 00$ & Southwest sensors hooked up \\
\hline $09: 30$ & ET battery not working, changed \\
\hline $10: 30$ & Buried Hydra probes at NW and E at $4 \mathrm{~cm}$ \\
\hline $11: 30$ & Buried SHF at all stations \\
\hline
\end{tabular}


March $22($ DoY 81)

\begin{tabular}{|l|l|}
\hline $08: 00$ & East deep sensors buried \\
\hline $11: 30$ & Soil samples taken from East area \\
\hline
\end{tabular}

March 24 (DoY 83)

\begin{tabular}{|l|l|}
\hline $08: 00$ & Radiometer restarted and records cleared \\
\hline $11: 30$ & TIR installed; 2 cm NW thermistor installed \\
\hline $13: 30$ & Herbicide application \\
\hline
\end{tabular}

$\underline{\text { March } 27 \text { (DoY 86) }}$

\begin{tabular}{|l|l|}
\hline $08: 00$ & Radiometer height (to trailer) measured at $5.5 \mathrm{~m}$ \\
\hline & Height of corn around $5 \mathrm{~cm}$ \\
\hline
\end{tabular}

$\underline{\operatorname{March}} 28$ (DoY 87)

\begin{tabular}{|l|l|}
\hline $08: 00$ & Radiometer data still having problems \\
\hline & Corn is wind damaged \\
\hline
\end{tabular}

March 29 (DoY 88)

\begin{tabular}{|l|l|}
\hline $08: 00$ & CNR installed \\
\hline $11: 30$ & IR turned from East-facing to South-facing \\
\hline
\end{tabular}

March 31 (DoY 90)

\begin{tabular}{|l|l}
\hline 08:00 & New H/V switch installed in radiometer; data restarted \\
\hline
\end{tabular}

April 4 (DoY 94)

\begin{tabular}{|l|l|}
\hline $08: 00$ & Mark vegetation sampling areas \\
\hline & Vegetation sampling \\
\hline & Cropscan \\
\hline
\end{tabular}

April 8 (DoY 94)

\begin{tabular}{|l|l|}
\hline $08: 00$ & Storm damage \\
\hline & Clear radiometer data and restart data; Dukes CNR-Lite started \\
\hline & TIR and hydraprobe bad \\
\hline
\end{tabular}

April 12 (DoY 102)

\begin{tabular}{|l|l|}
\hline $08: 00$ & Vegetation sampling \\
\hline & Cropscan \\
\hline & Radiometer calibration \\
\hline & Hand-transplanted footprint \\
\hline
\end{tabular}


April 19 (DoY 109)

\begin{tabular}{|l|l|}
\hline $08: 00$ & Vegetation sampling \\
\hline & Cropscan \\
\hline & Corn yellowish: nitrogen stress from leaching \\
\hline
\end{tabular}

$\underline{\text { April 26 (DoY 116) }}$

\begin{tabular}{|l|l|}
\hline $11: 00$ & Vegetation sampling \\
\hline & Cropscan \\
\hline & Radiometer calibration \\
\hline & TIR damaged again \\
\hline
\end{tabular}

May $3($ DoY 123)

\begin{tabular}{|l|l|}
\hline $11: 00$ & Vegetation sampling \\
\hline & Cropscan \\
\hline
\end{tabular}

May $6($ DoY 126)

May 10 (DoY 130)

\begin{tabular}{|l|l|}
\hline $08: 00$ & Vegetation sampling \\
\hline & Cropscan \\
\hline $09: 40$ & ECS battery change \\
\hline
\end{tabular}

\begin{tabular}{|l|l|}
\hline $08: 00$ & Vegetation sampling \\
\hline & Cropscan \\
\hline & Tassel initiation in SE, NE \\
\hline
\end{tabular}

May 12 (DoY 132)

\begin{tabular}{|l|l|}
\hline $08: 00$ & Roughness measurement \\
\hline & Canopy Opacity \\
\hline & Almost full tasseling in Northeast side \\
\hline
\end{tabular}

May $13($ DoY 133)

\begin{tabular}{|l|l|}
\hline & Almost full tasseling in Northwest side \\
\hline
\end{tabular}

May 17 (DoY 137)

08:00 Radiometer found overheated; cleaned out fan and restarted; data gap DoY 136 - 141

Canopy Opacity

Full tasseling, 50-75\% silking

May 20 (DoY 140)

\begin{tabular}{|l|l|}
\hline $08: 00$ & Roughness measurement \\
\hline & $\begin{array}{l}\text { NW station died; recharged battery; problem with power } \\
\text { supply }\end{array}$ \\
\hline & Grain fill has started \\
\hline
\end{tabular}

May 23 (DoY 143)

\begin{tabular}{|l|l|}
\hline $11: 00$ & CSAT moved up from $1 \mathrm{~m}$ to $2.1 \mathrm{~m}$ \\
\hline
\end{tabular} 
May 24 (DoY 144)

\begin{tabular}{|l|l|}
\hline $08: 00$ & Power supply fixed \\
\hline & Half of vegetation sampling (NW and SW) \\
\hline
\end{tabular}

May 25 (DoY 145)

\begin{tabular}{|l|l|}
\hline $08: 00$ & Cropscan \\
\hline & Other half of vegetation sampling (NE and SE) \\
\hline & Change ECS battery \\
\hline
\end{tabular}

May $26($ DoY 146)

\begin{tabular}{|l|l|}
\hline $08: 00$ & Rotator motor problem; unable to change radiometer angle \\
\hline & Canopy opacity \\
\hline & Soil roughness \\
\hline
\end{tabular}

June 2 (DoY 153)

\begin{tabular}{|l|l|}
\hline $08: 00$ & Vegetation sampling \\
\hline $08: 30$ & Vegetation sampling in footprint \\
\hline $09: 45$ & LAI in footprint \\
\hline $11: 00$ & Remove ears in footprint \\
\hline
\end{tabular}

June 4 (DoY 155)

\begin{tabular}{|l|l|}
\hline 13:00 & Remove leaves in footprint (out at 15:00) \\
\hline
\end{tabular}

June 6 (DoY 157)

\begin{tabular}{|l|l}
\hline 13:00 & Radiometer overheated (9:00 156), rebooted it \\
\hline
\end{tabular}

$\underline{\text { June } 14 \text { (DoY 165) }}$

\begin{tabular}{|l|l|}
\hline $13: 00$ & Radiometer calibration \\
\hline & Sensor removal \\
\hline
\end{tabular}




\section{REFERENCES}

Campbell Scientific, CSAT3 Three Dimensional Sonic Anemometer Instruction Manual, Campbell Scientific Inc., Logan, UT, 1998.

Campbell Scientific, HFT3 Soil heat flux plate instruction manual, Campbell Scientific Inc., Logan, UT, 2003.

Campbell Scientific, CNR1 Net Radiometer Instruction Manual, Campbell Scientific Inc., Logan, UT, 2005a.

Campbell Scientific, CS615 and CS625 water content reflectometers instruction manual, Campbell Scientific Inc., Logan, UT, 2005b.

J.J. Casanova, M.Y. Jang, and J. Judge, Vertical distribution of moisture in the corn canopy, Center for Remote Sensing Technical Note \# 06CAS, 2006.

M.Y. Jang, K.C. Tien, J.J. Casanova, and J. Judge, Measurements of soil surface roughness during the fourth microwave water and energy balance experiment: April 18 through June 13, 2005, Circular \# 1483, Center of Remote Sensing, UF/IFAS EDIS Web site, Available at: http://edis.ifas.ufl.edu/AE363, 2005.

Everest Interscience, Model 4000.3ZL Infrared Temperature Sensor, Everest Interscience Inc., Tuson, AZ, 2005.

J. C. Kaimal and J. J. Finnigan, Atmospheric Boundary Layer Flows, Oxford University Press, New York, NY, 1994.

R. D. De Roo, University of Florida C-band Radiometer Summary, Space Physics Research Laboratory, University of Michigan, Ann Arbor, MI, March, 2002.

R. D. De Roo, TMRS-3 Radiometer Tuning Procedures, Space Physics Research Laboratory, University of Michigan, Ann Arbor, MI, March, 2003.

P. Schotanus, F. T. M. Nieuwstadt, and H. A. R. DeBruin, "Temperature measurement with a sonic anemometer and its application to heat and moisture fluctuations," Bound.-Layer Meteorol., vol. 26, pp. 81-93, 1983.

A. van Dijk, W. Kohsiek, and H. A. R. DeBruin, "Oxygen sensitivity of krypton and Lyman-alpha hygrometer,” J. Atmos. Ocean. Tech., vol. 20, pp. 143-151, 2003.

A. van Dijk, A. F. Moene, and H. A. R. DeBurin, The Principles of Surface Flux Physics: Theory, Practice, and Description of the ECPACK Library, http://www.met.wau.nl/projects/jep/

E. K. Webb, G. I. Pearman, and R. Leuning, “ Correction of flux measurements for density effects due to heat and water vapor transfer," Quart. J. Roy. Meteorol., Soc., vol. 106, pp. 85-100, 1980. 
J. M. Wilczak, S. P. Oncley, and S. A. Stage, "Sonic anemometer tilt correction algorithms," Bound.-Layer Meteorol., vol. 99, pp. 127-150, 2001.a

\section{ACKNOWLEDGEMENTS}

This research was supported by funding from the NASA-New Investigator Program Grant \#0005065. The authors would like to thank Mr. James Boyer and his team at the PSREU for land and crop management.

\section{Figure Captions}

\section{A. FIELD OBSERVATIONS}

Figure A-1 Microwave brightness at vertical and horizontal polarizations; surface temperature............18

Figure A-2 Latent and sensible heat fluxes.....................................................

Figure A-3 Down- and up- welling short- and long- wave radiation................................20

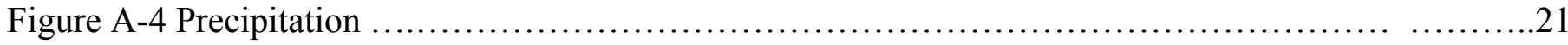

Figure A-5 Northwest station soil temperature................................................22

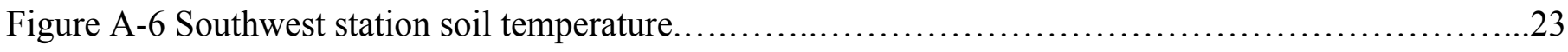

Figure A-7 East station soil temperature .............................................. 24

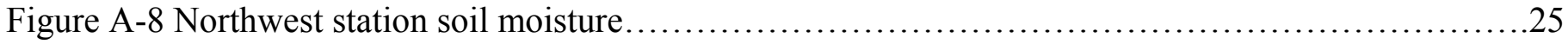

Figure A-9 Southwest station soil moisture ...............................................26

Figure A-10 East station soil moisture .....................................................27

Figure A-11 CSAT, Northwest, East, and Southwest station soil heat fluxes..........................28

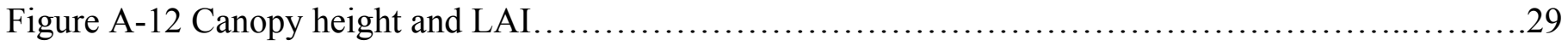

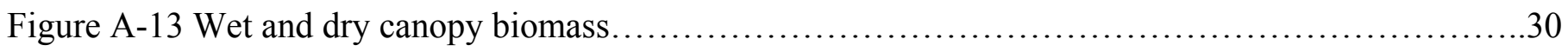

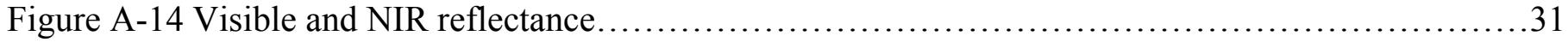

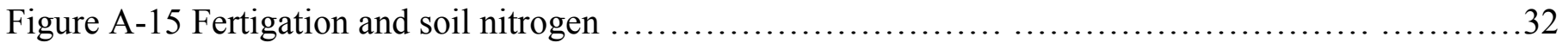

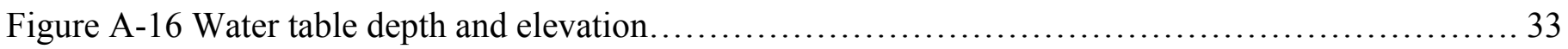



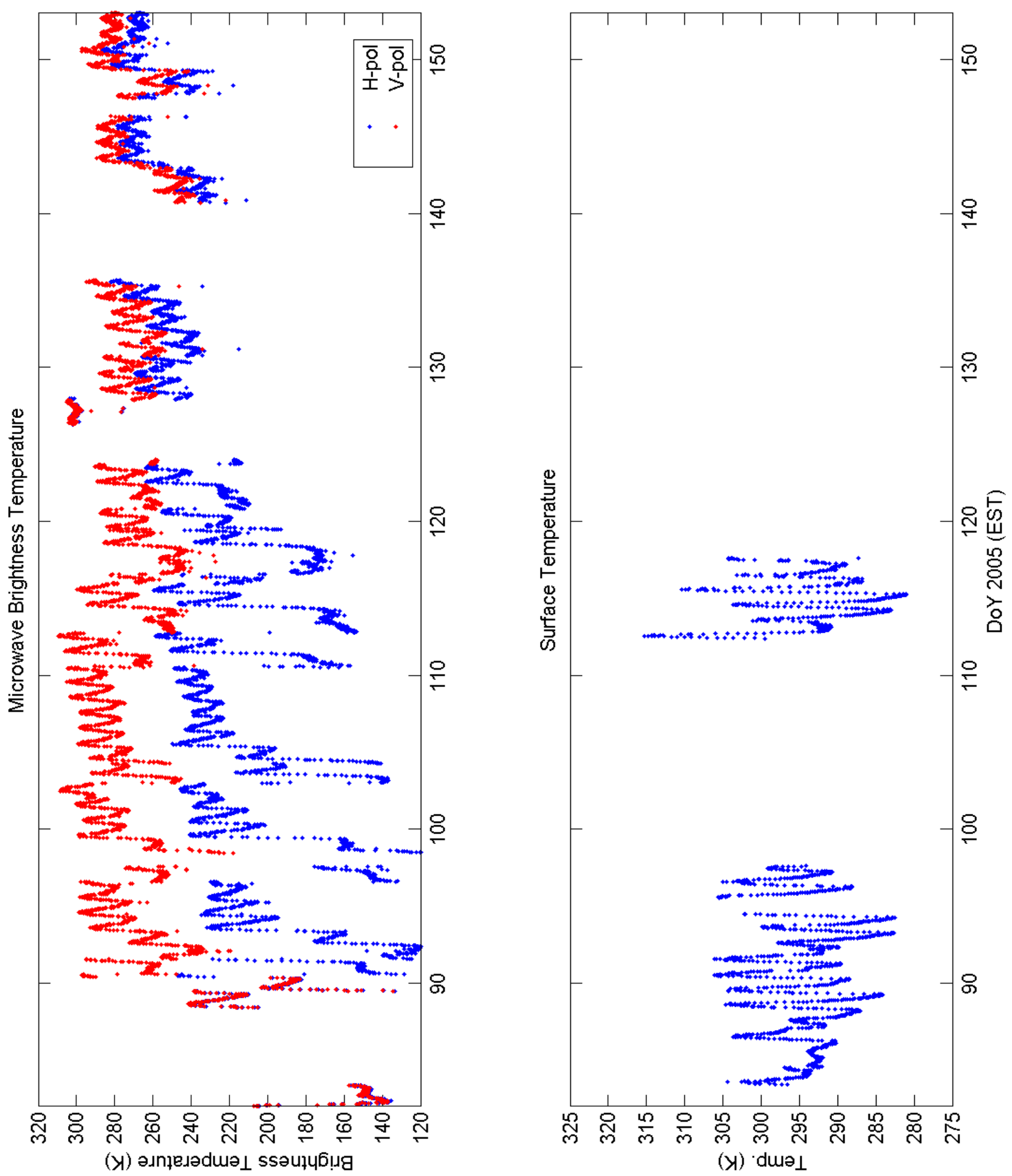

Figure A- 1 Microwave brightness at vertical and horizontal polarizations; surface temperature 


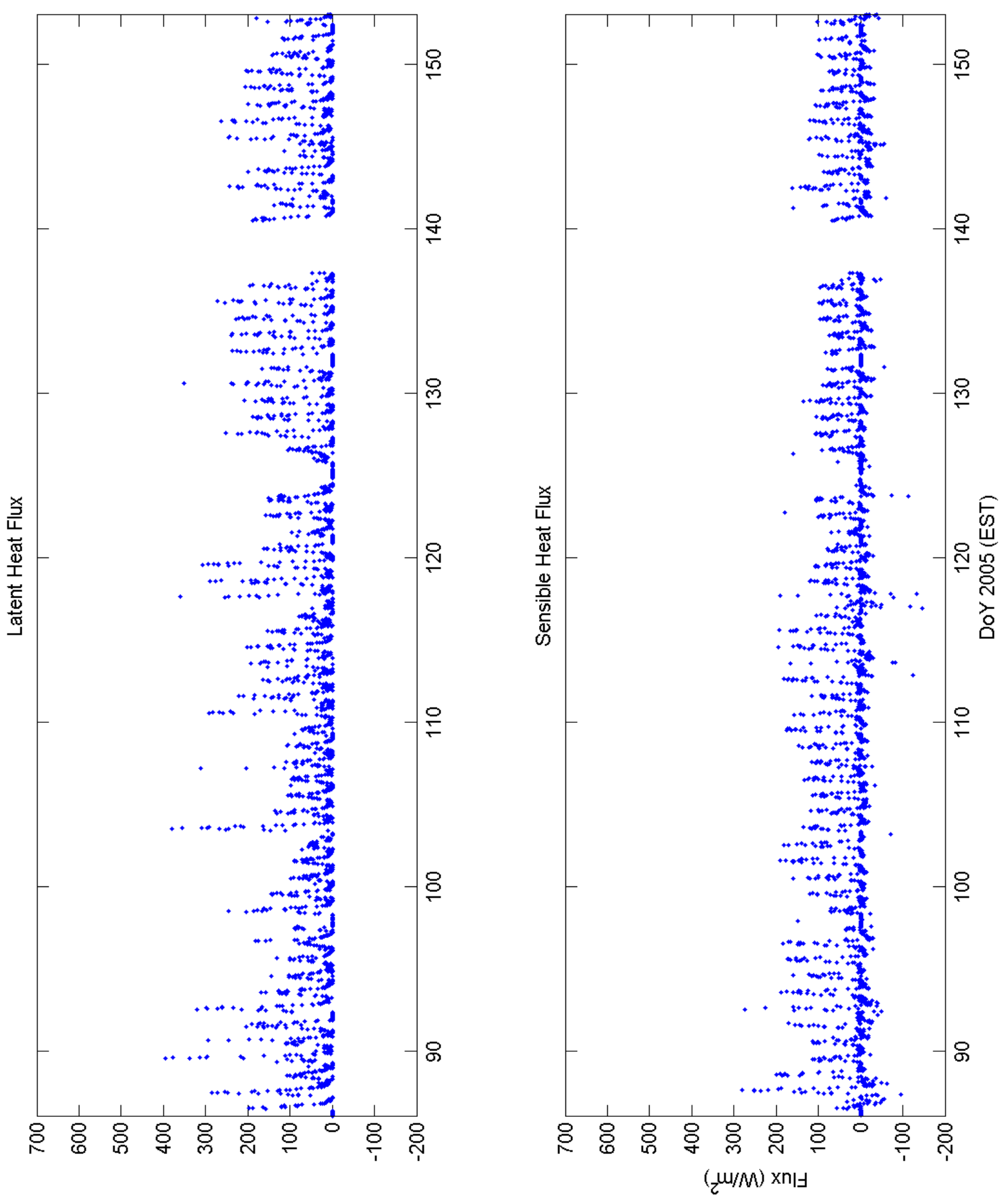

Figure A- 2 Latent and sensible heat fluxes 

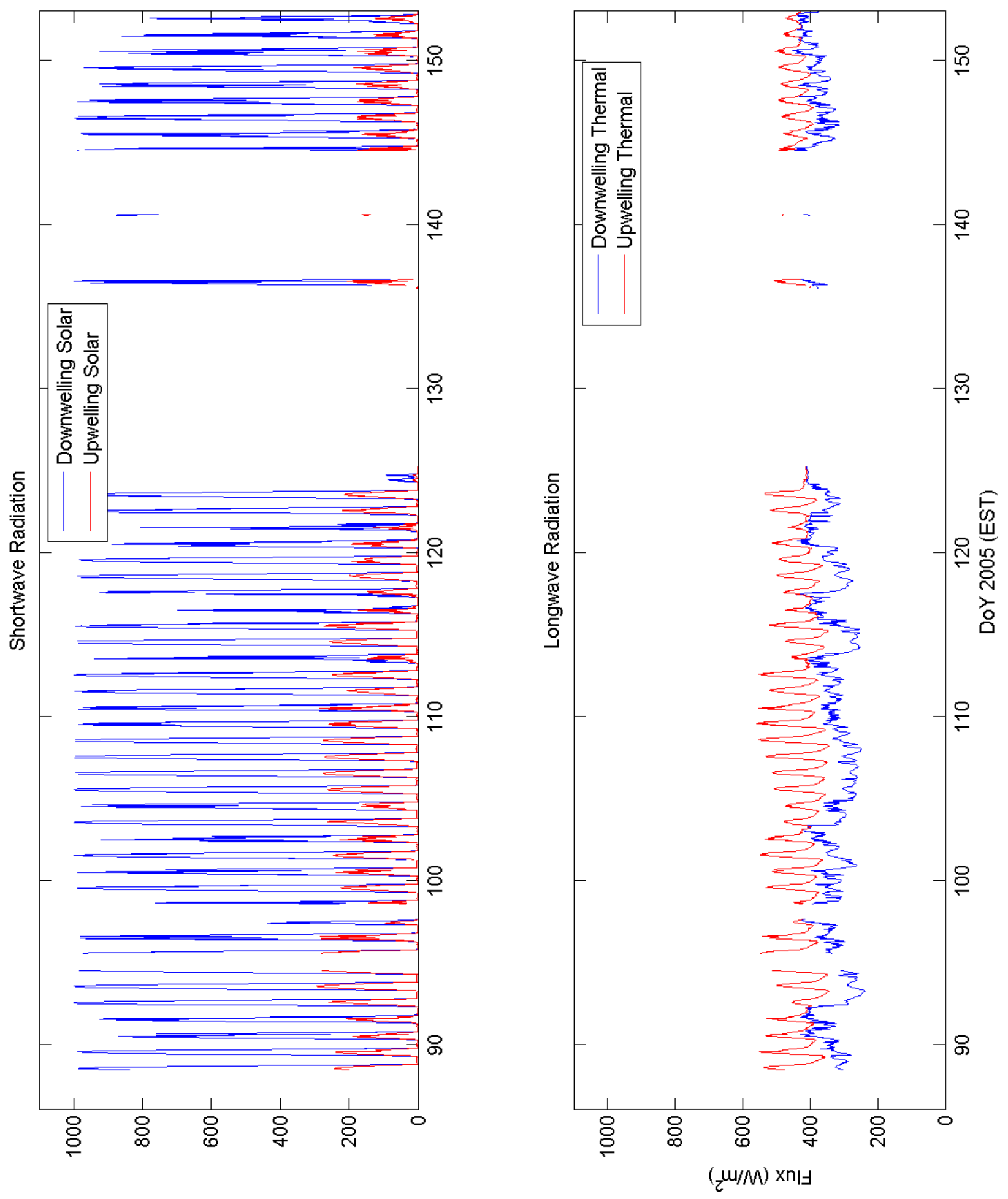

Figure A- 3 Down- and up- welling short- and long- wave radiation 

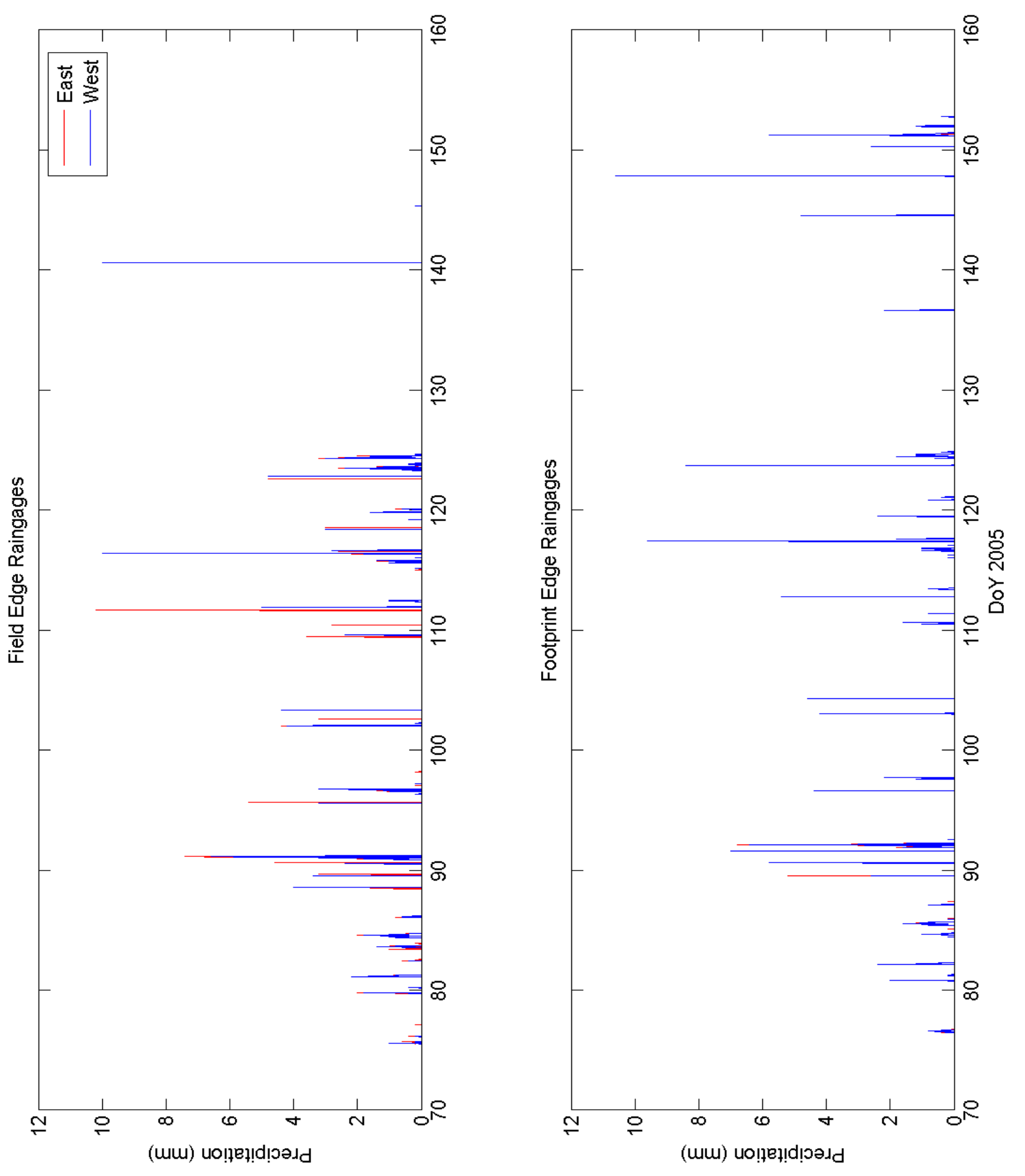

Figure A- 4 Precipitation 


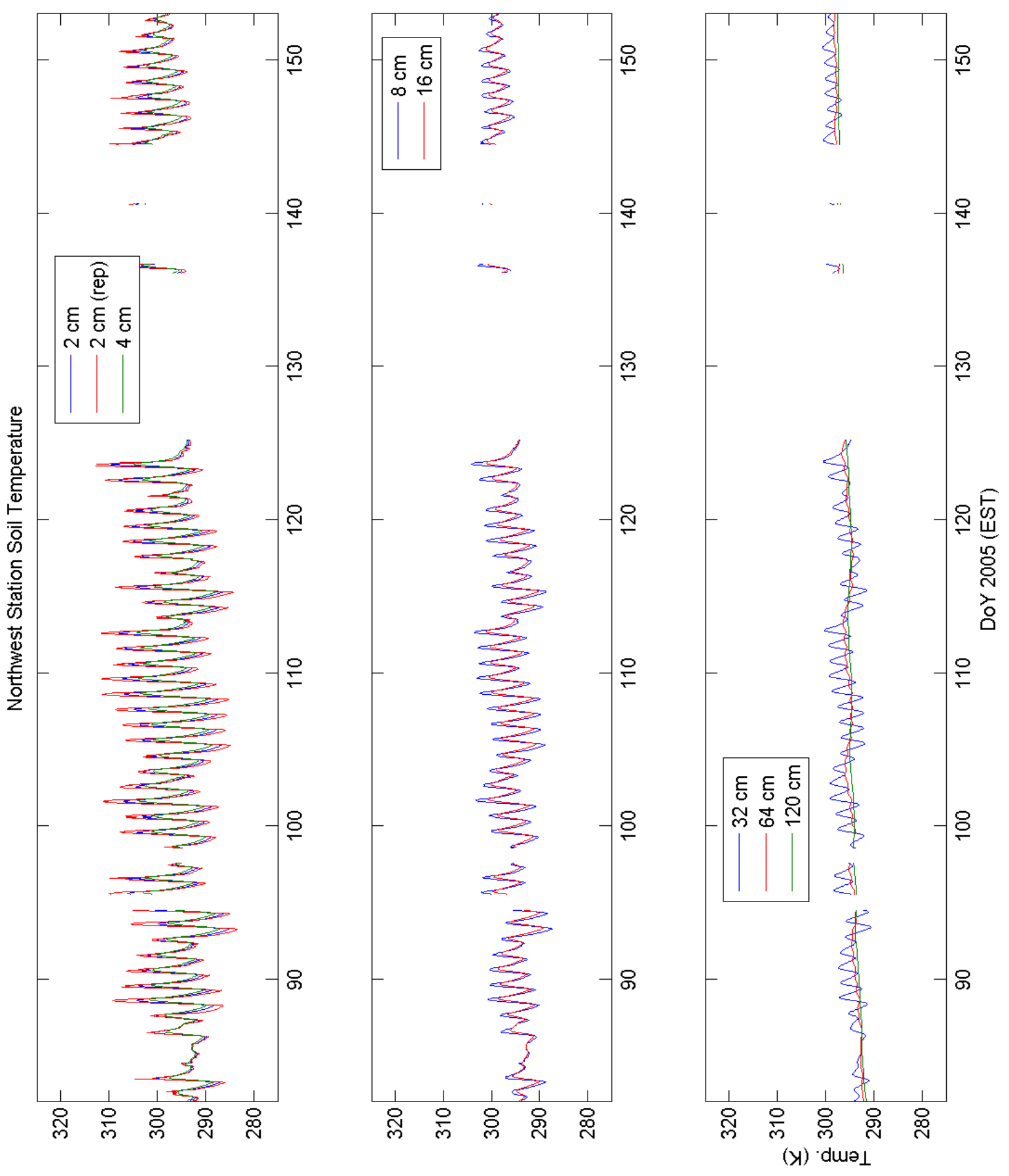

Figure A- 5 Northwest station soil temperature 


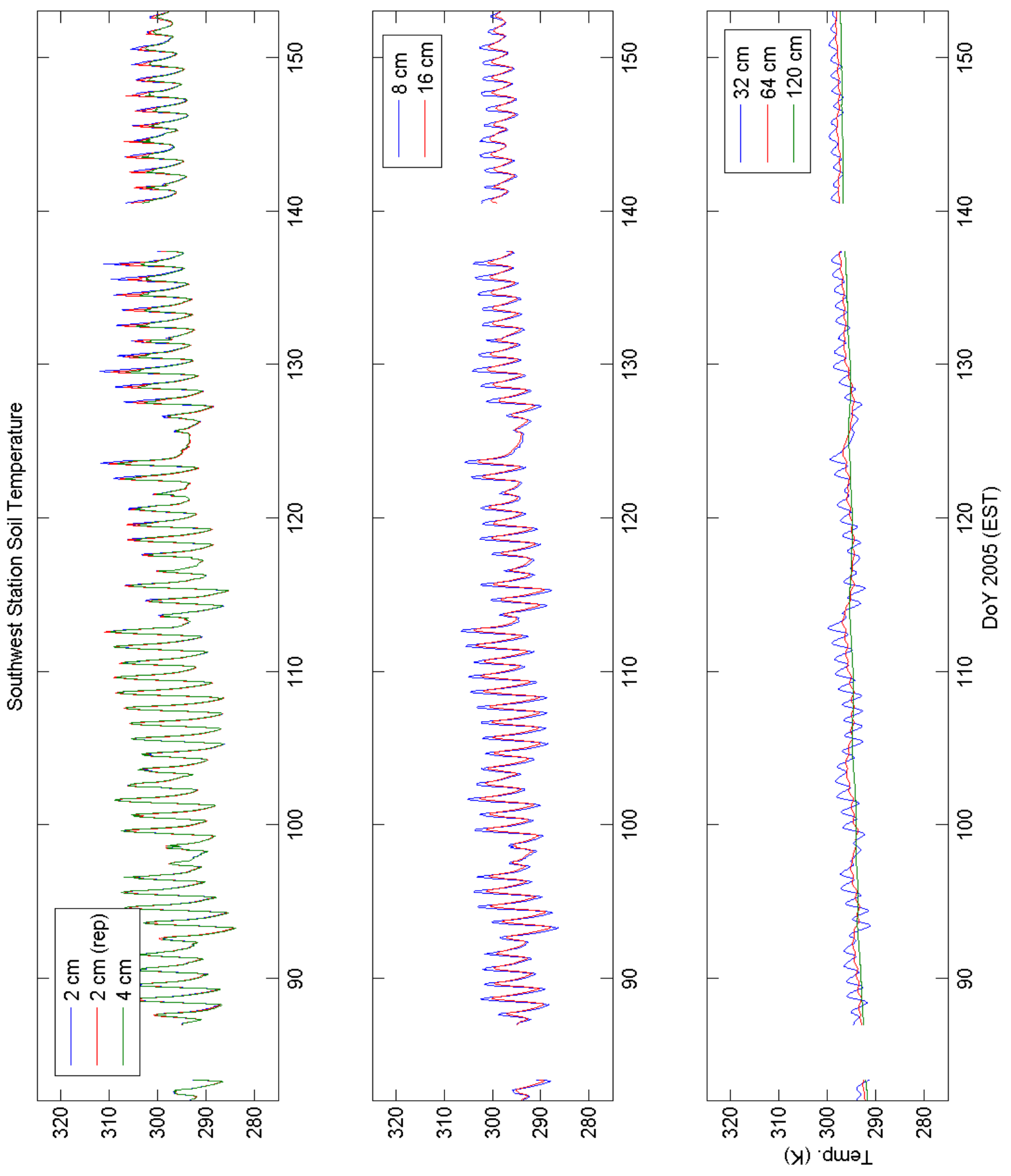

Figure A- 6 Southwest station soil temperature 

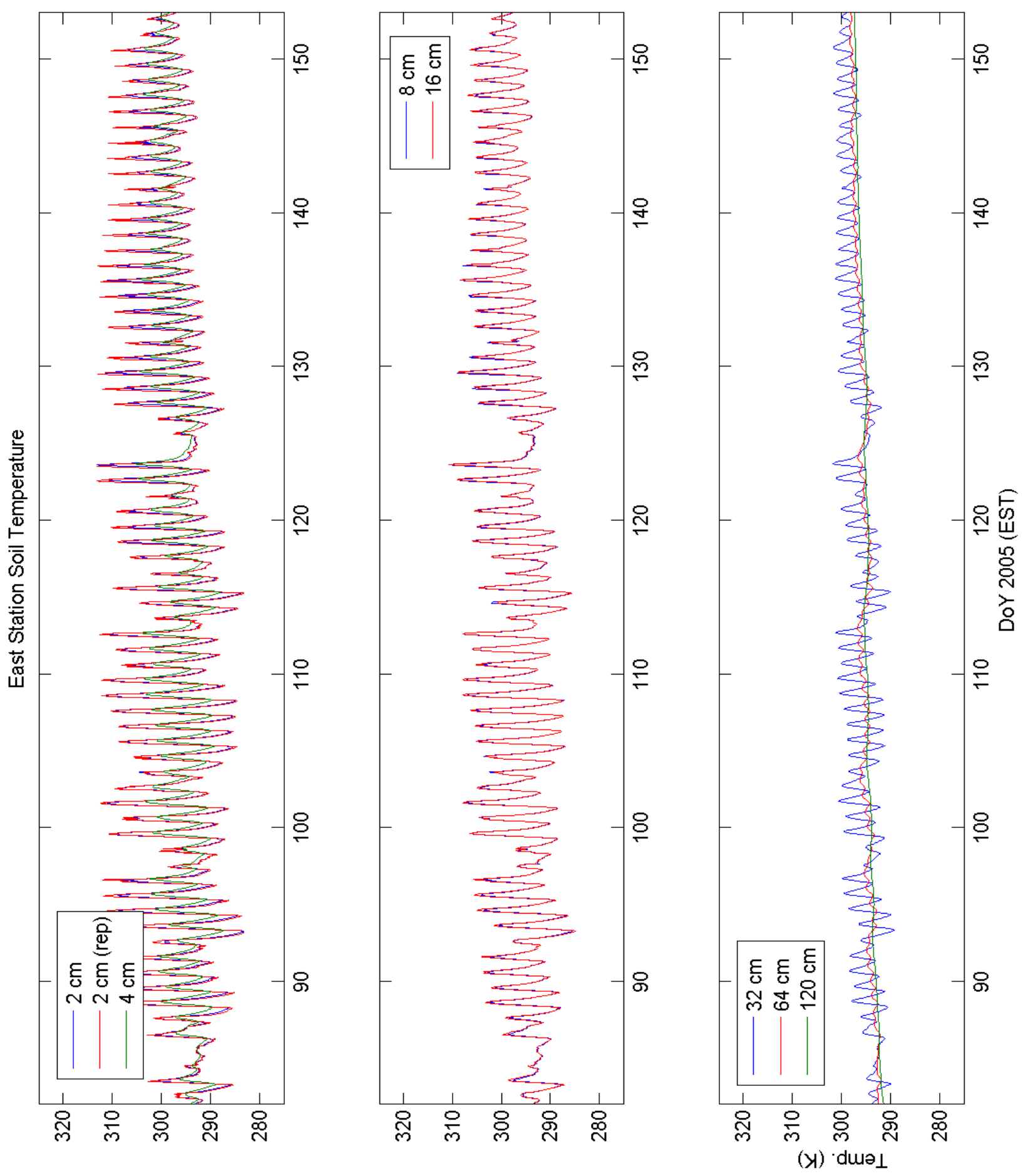

Figure A- 7 East station soil temperature 


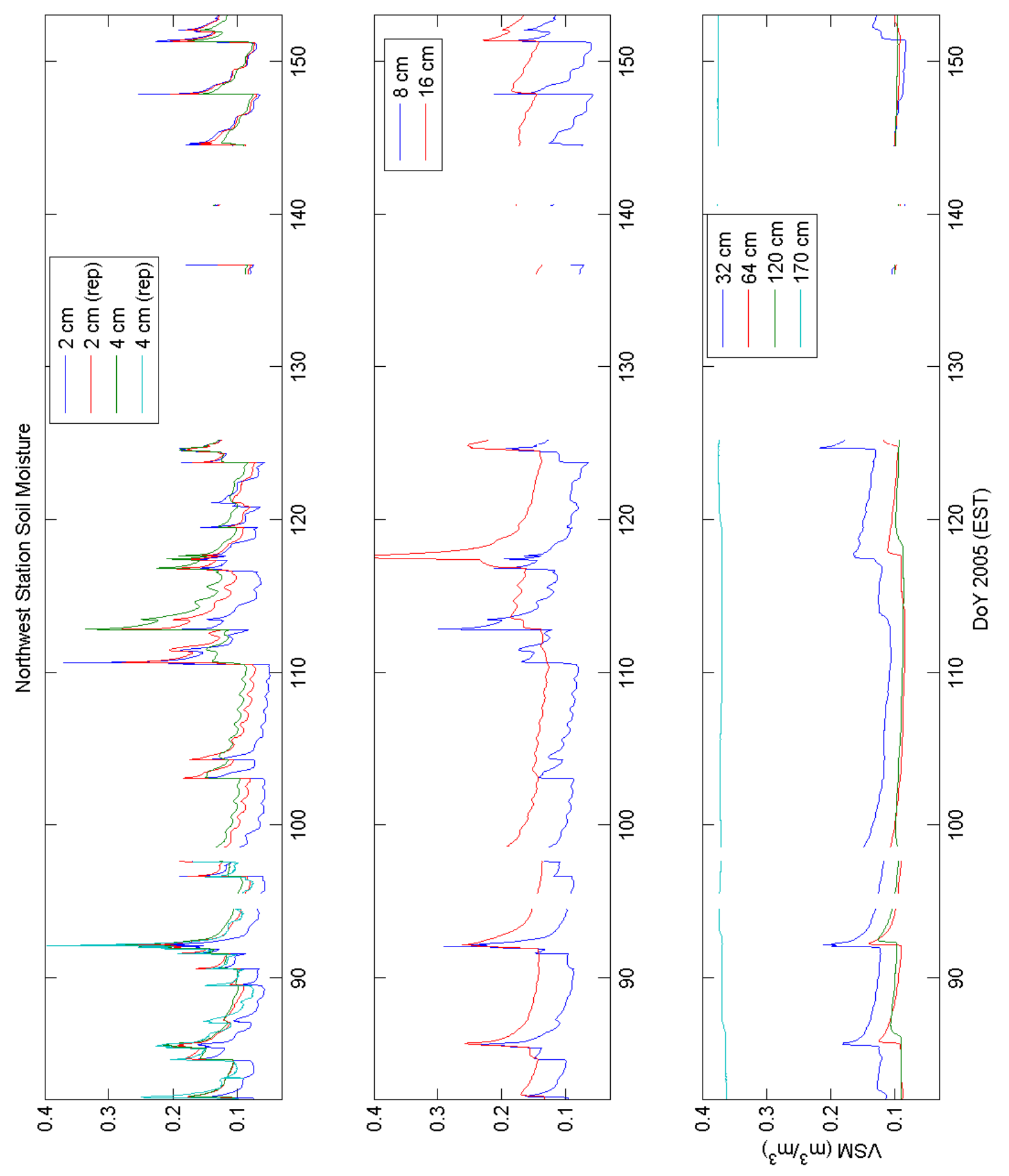

Figure A- 8 Northwest station soil moisture 

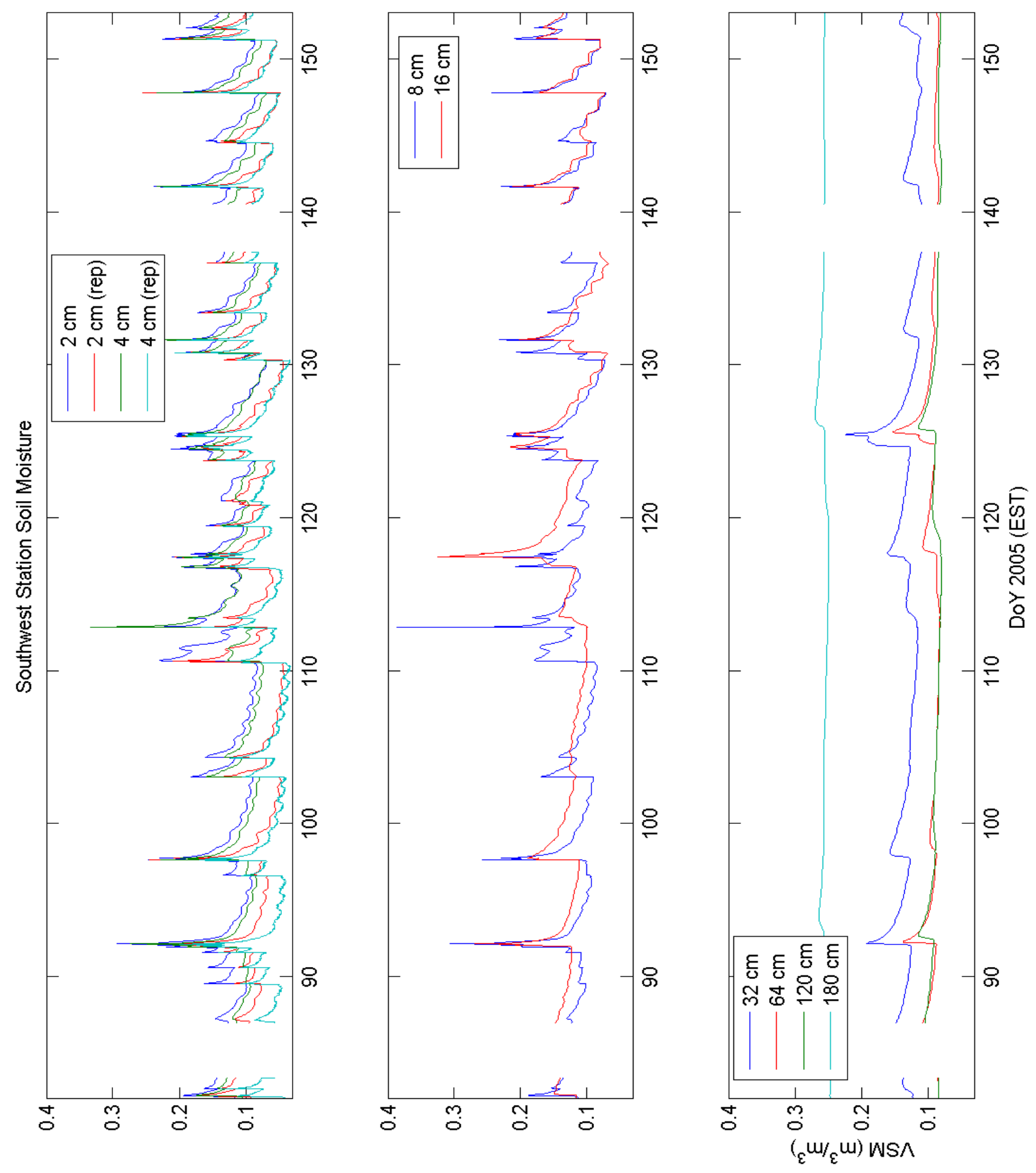

Figure A- 9 Southwest station soil moisture 


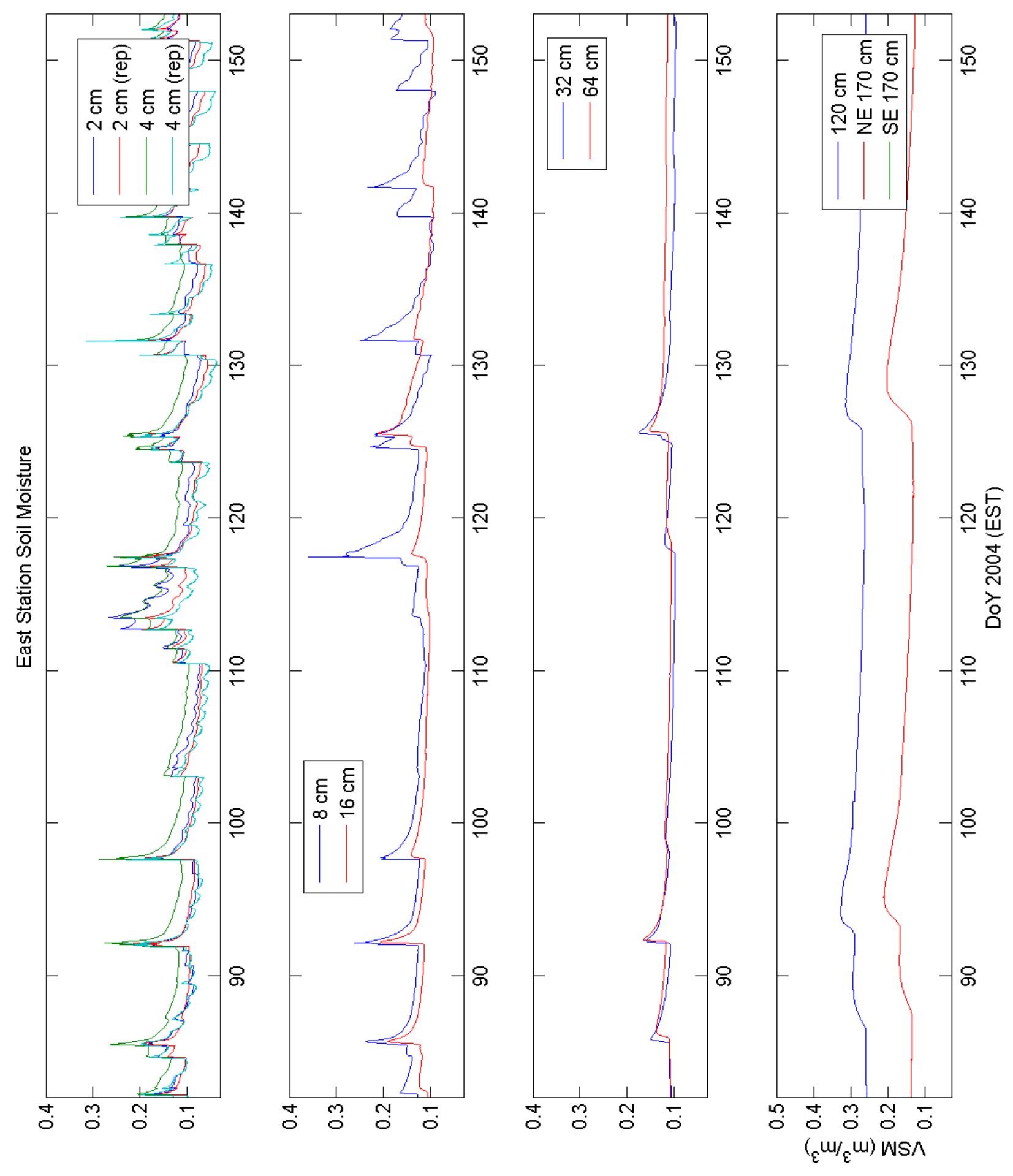

Figure A- 10 East station soil moisture 


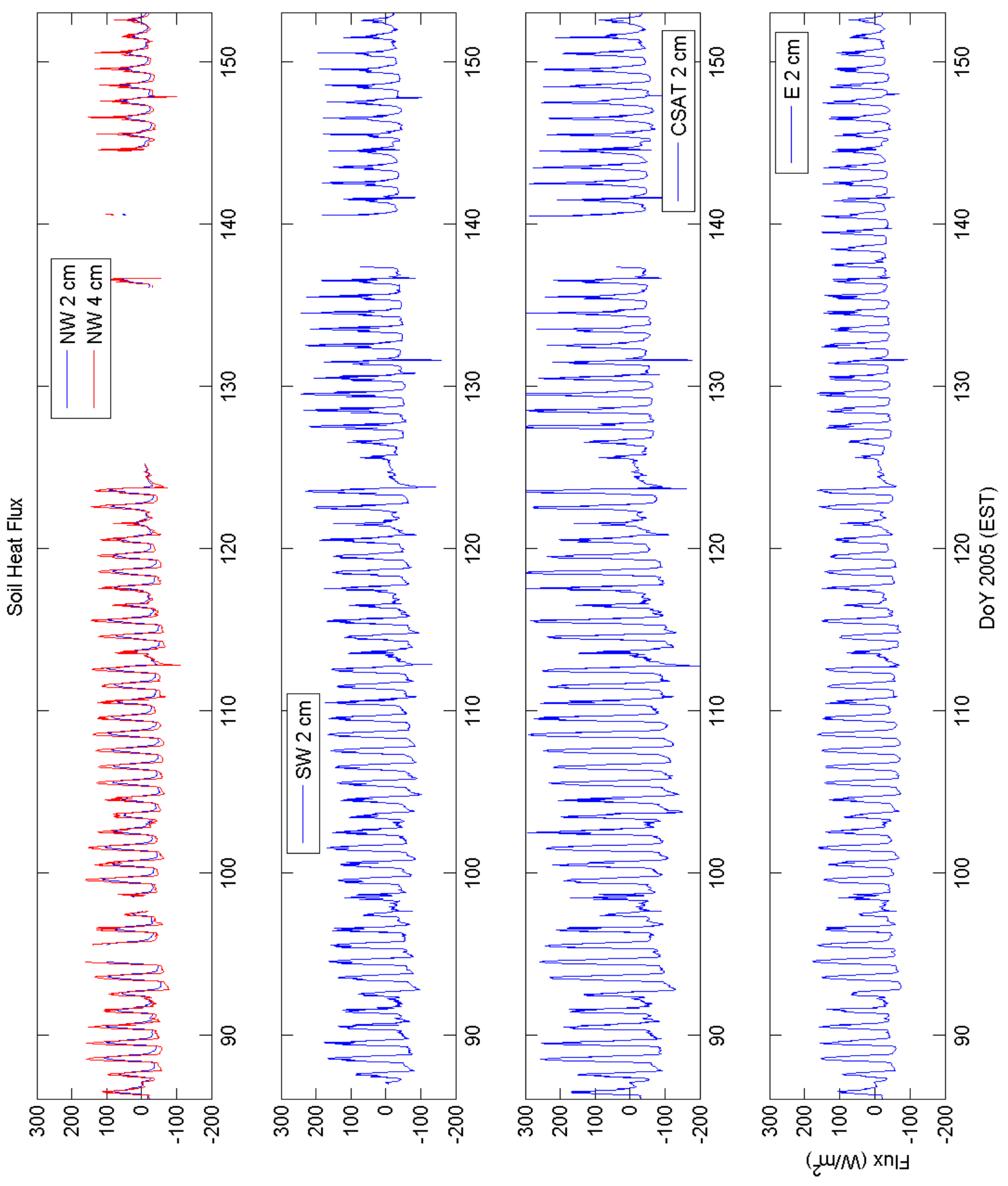

Figure A- 11 CSAT, Northwest, East, and Southwest station soil heat fluxes 


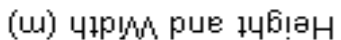

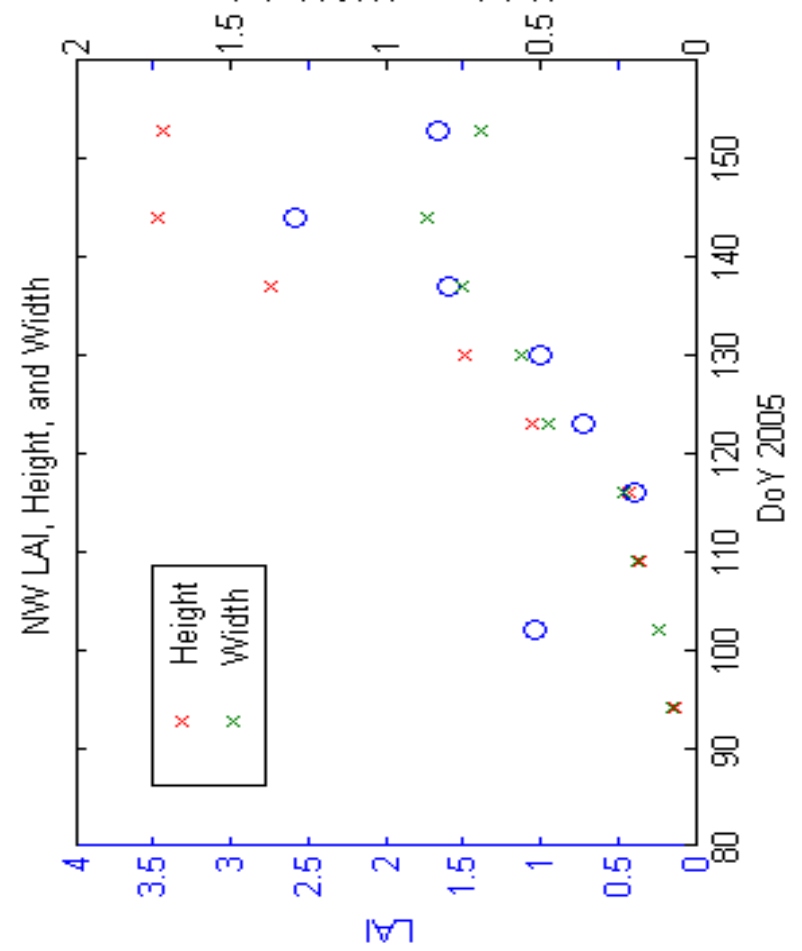

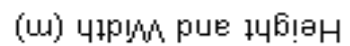

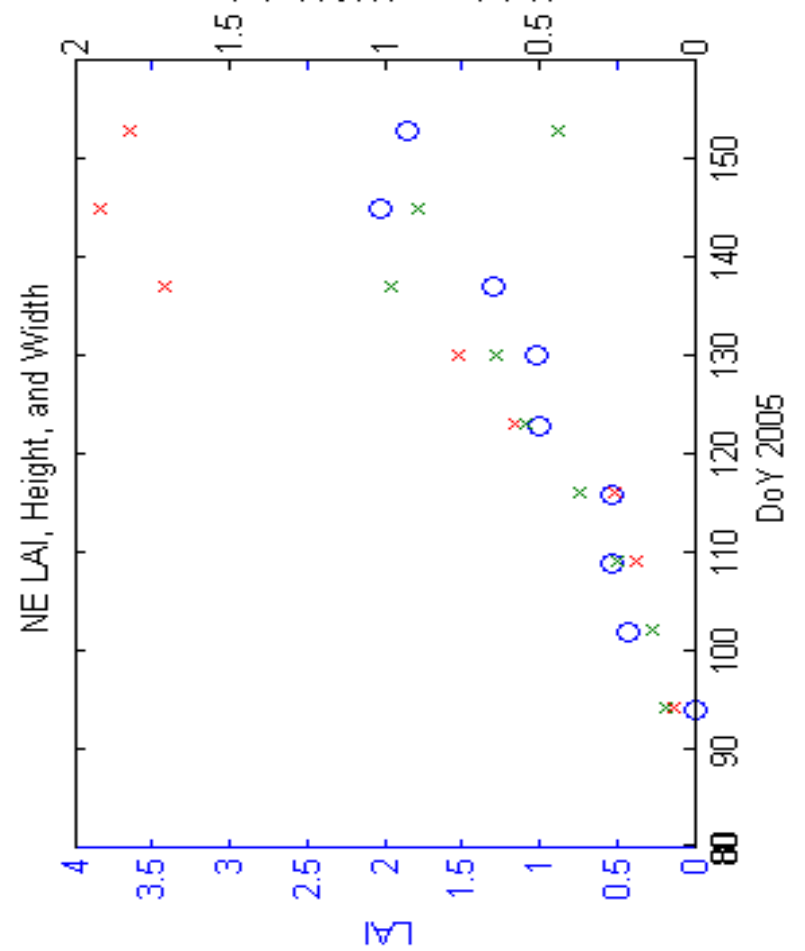

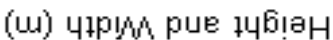

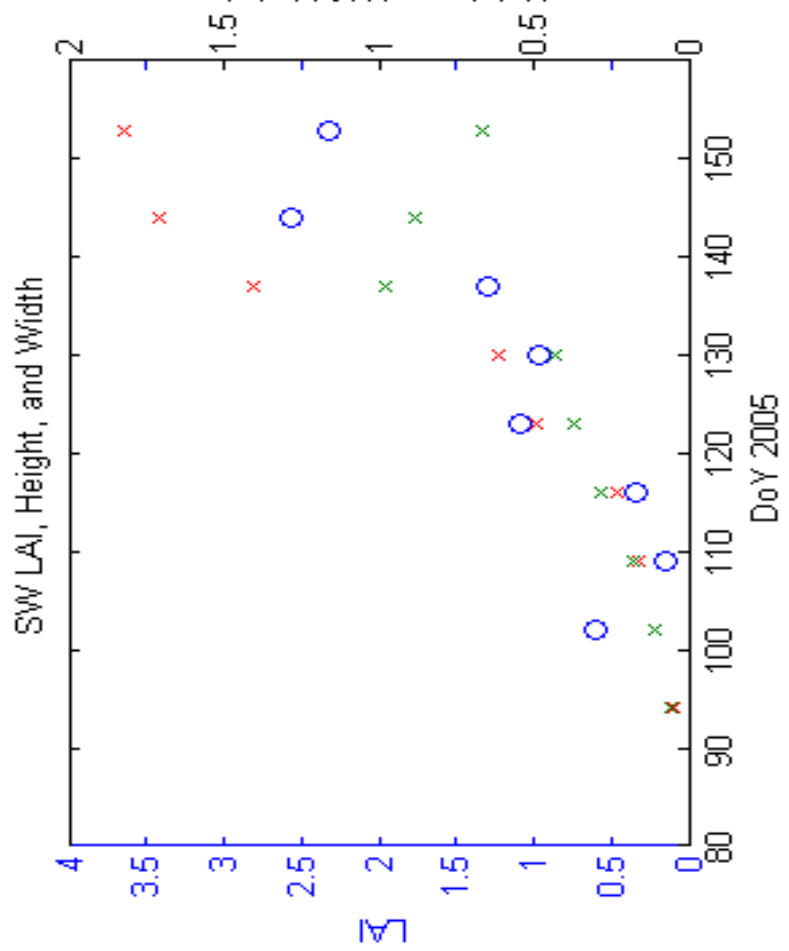

(u) чІрМ рue 746 !ан

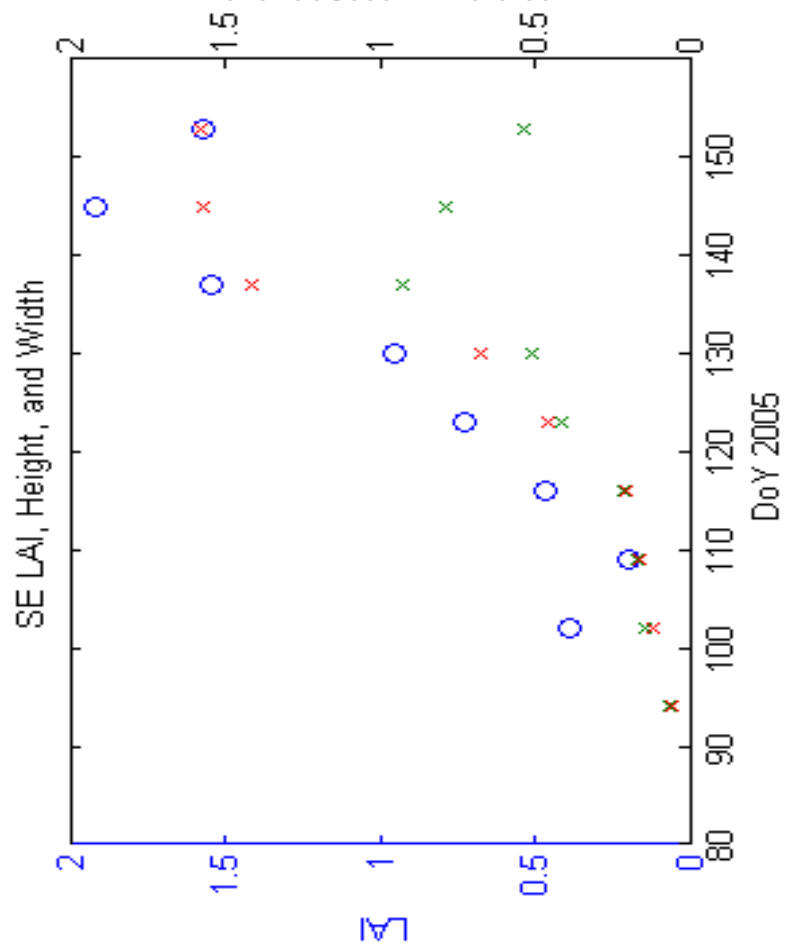

Figure A- 12 Canopy height, width, and LAI 

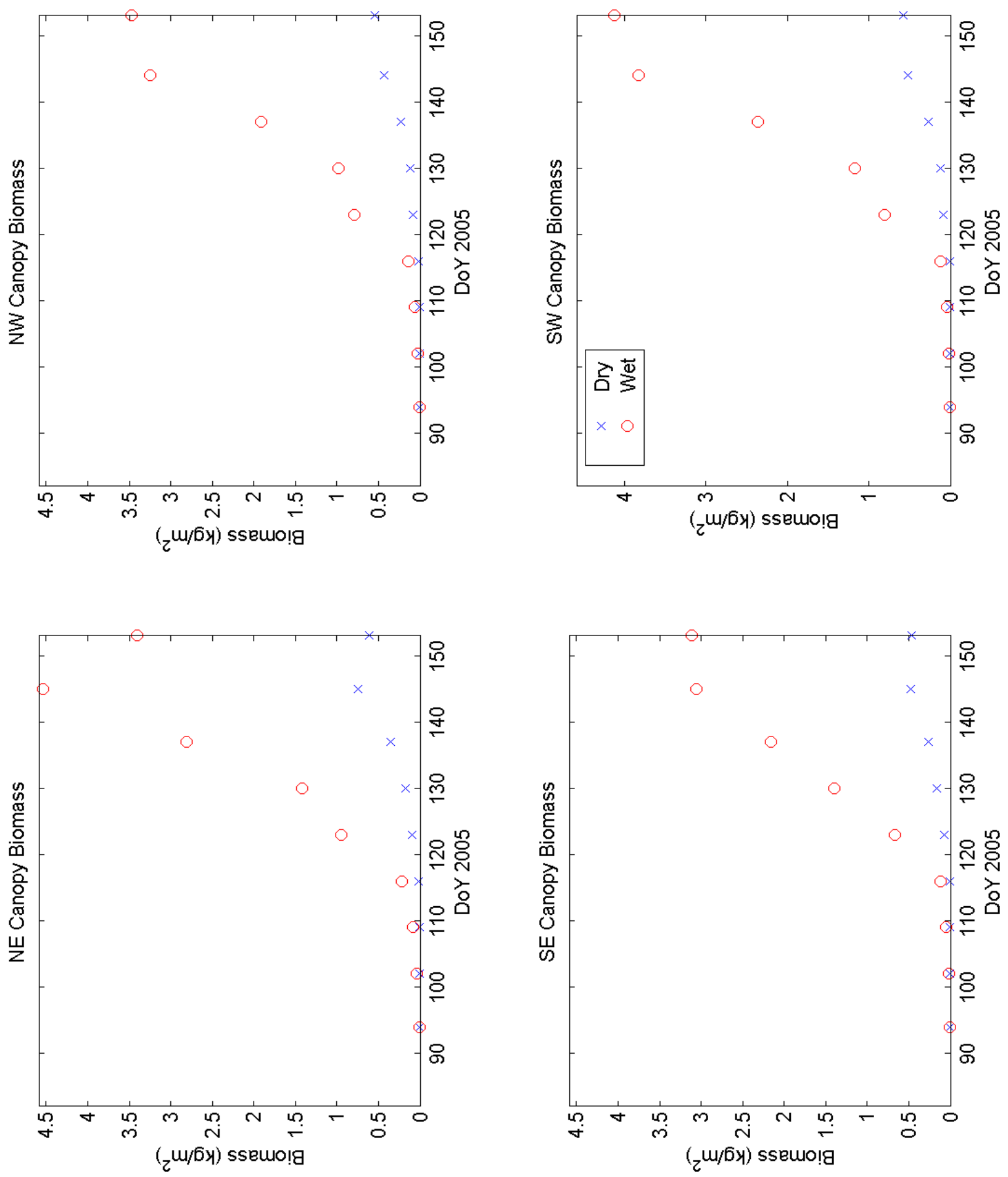

Figure A- 13 Wet and dry canopy biomass 

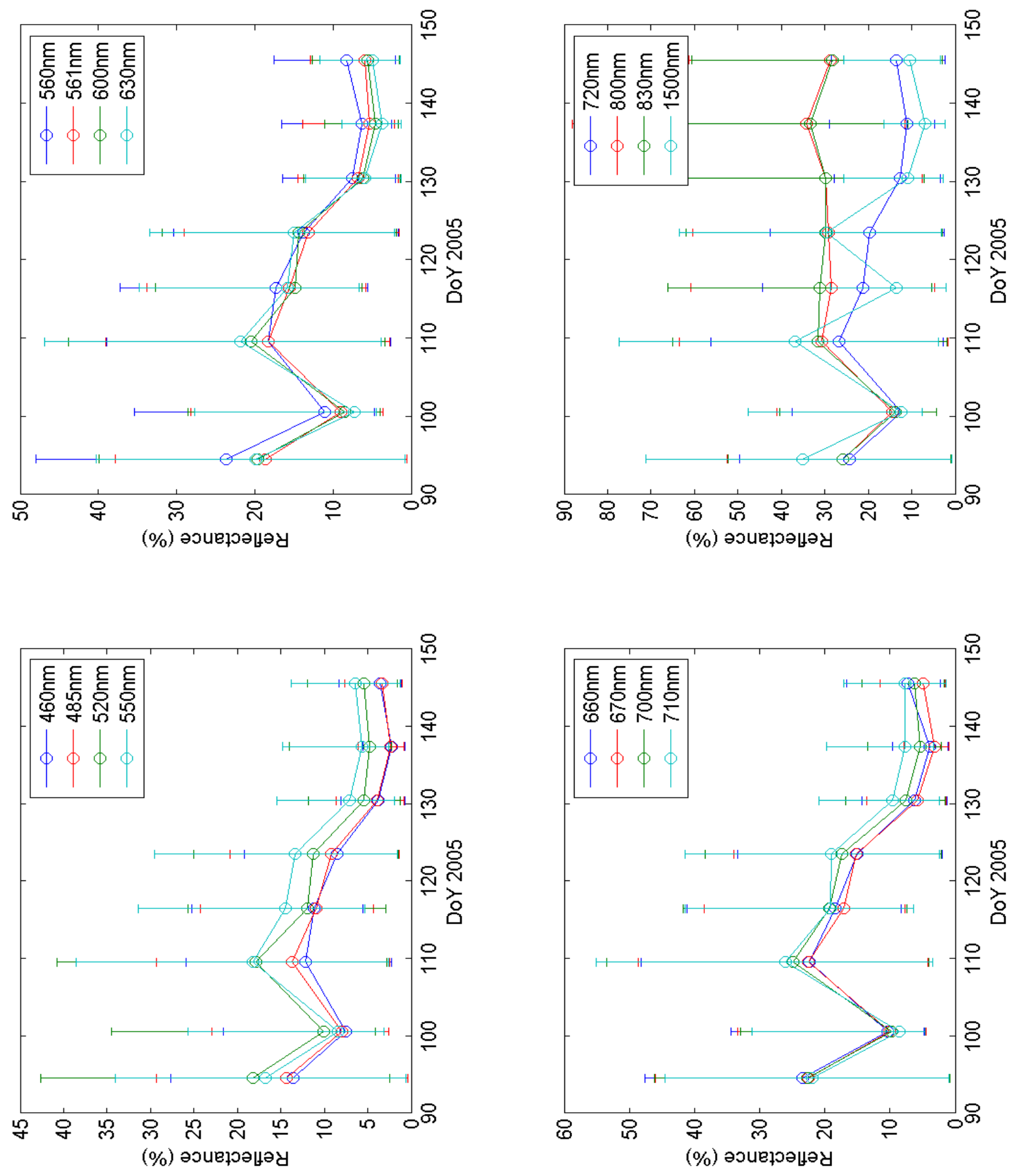

Figure A- 14 Visible and NIR reflectances 

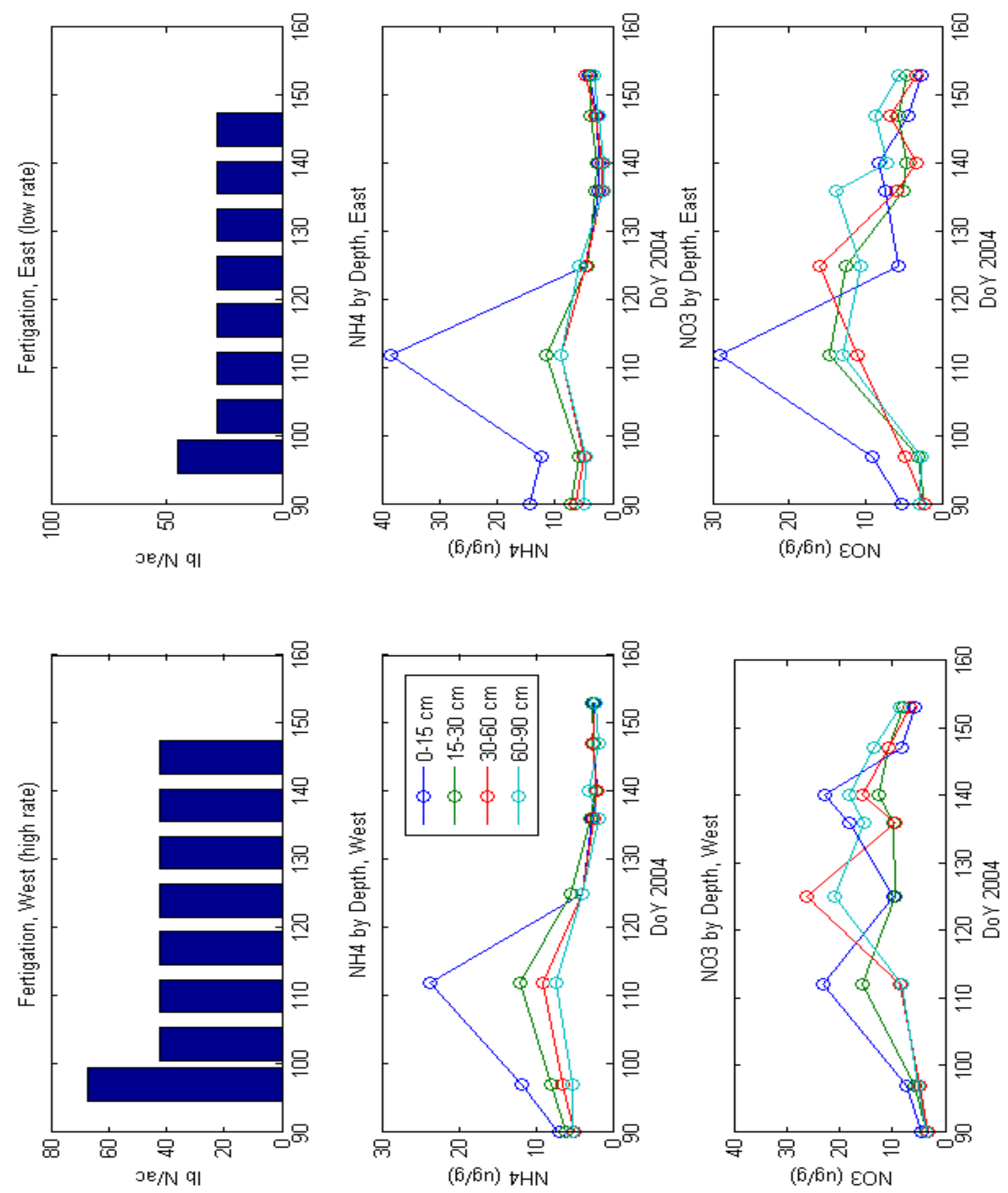

Figure A- 15 Fertigation and soil nitrogen 


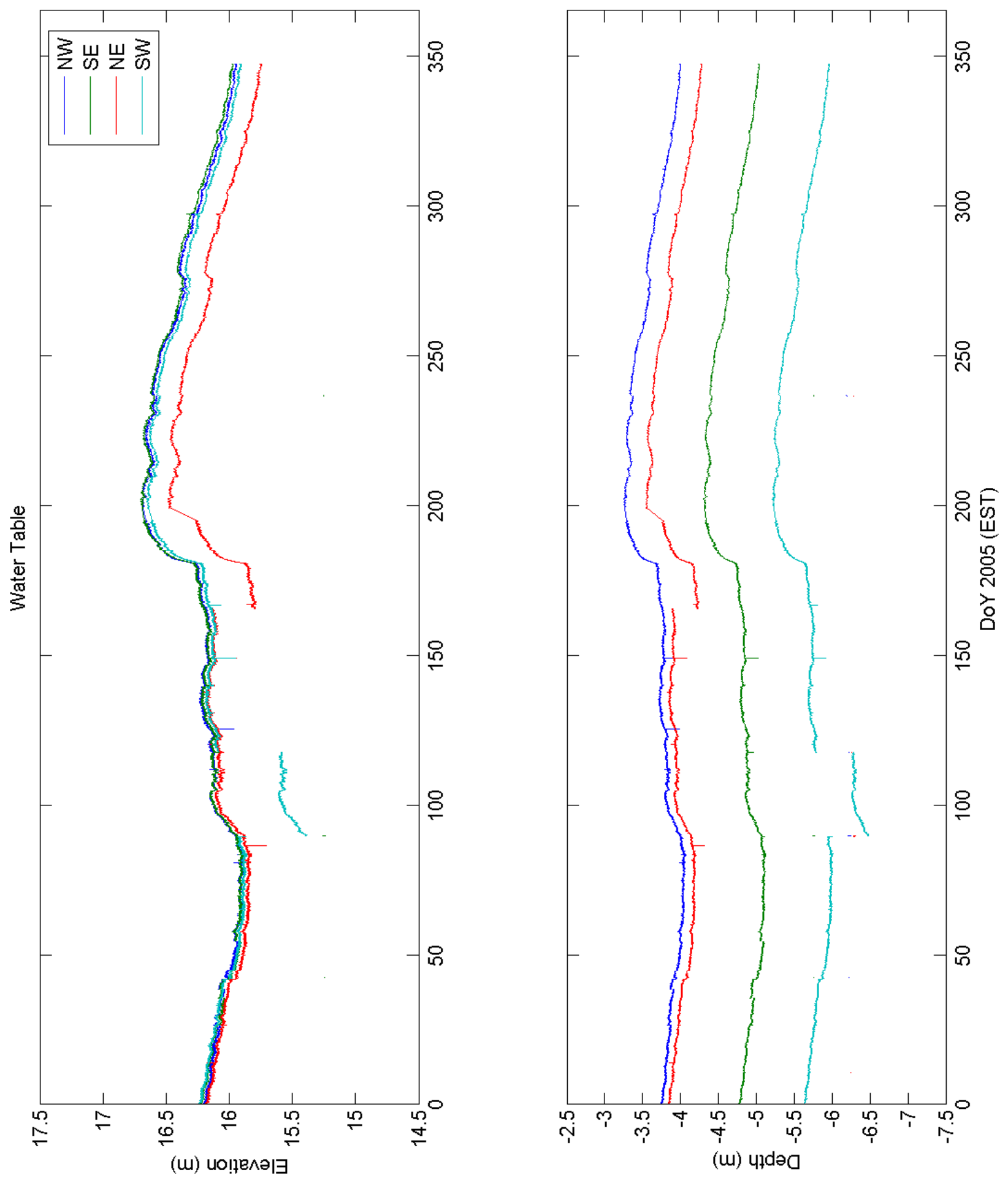

Figure A- 16 Water table depth and elevation 